
terms of use apply: https://www.sprin

\title{
Resilience and protective factors among people with a history of child maltreatment: A systematic review
}

\section{Xiangfei Meng ${ }^{1,2}$ Marie-Josee Fleury ${ }^{1,2}$ Yu-Tao Xiang ${ }^{3}$ Muzi Li $^{4}$ Carl D’Arcy $^{4,5}$}

Xiangfei Meng xiangfei.meng@mcgill.ca

${ }^{1}$ Department of Psychiatry, Faculty of Medicine, McGill University, Montreal, QC

Canada

${ }^{2}$ Douglas Mental Health University Institute, Montreal, QC Canada

${ }^{3}$ Faculty of Health Sciences, University of Macau, Macao SAR, China

${ }^{4}$ School of Public Health, University of Saskatchewan, Saskatoon, SK Canada

${ }^{5}$ Department of Psychiatry, College of Medicine, University of Saskatchewan,

Saskatoon, SK Canada

Text: 4546 words

Abstract: 247 words

Tables:3

Figures:2 
This is a post-peer-review, pre-copyedit version of an article published in 'Social Indicators Research'. The final authenticated version is available online at: https://doi.org/10.1007/s11205-015-0941-6. The following terms of use apply: https://www.sprin

\section{Abstract}

Purpose To provide an overview of resilience and protective factors associated with a better life following child maltreatment exposure, to compare protective factors across specific subtypes of maltreatment, and to explore existing issues in the current state of the literature.

Methods Electronic databases and grey literature up to October 2017 were systematically searched for English language with observational study designs for the research on resilience and childhood maltreatment. Systematic review and qualitative approaches were used to synthesize the results. Study quality and heterogeneity were also examined. Results Initial screening of titles and abstracts resulted in 247 papers being reviewed. A total of 85 articles met eligibility criteria of this review. Most of these studies had low or middle study quality. There were two subgroups of studies reviewed: 1) 11 studies examined whether resilience protected against the negative consequence of childhood maltreatment, and, 2) 75 studies explored what protective factor was associated with a kind of adaptive functioning. Although the conceptualization of resilience significantly varied from study to study, protective factors associated with resilience at individual, familial, and societal levels reduced the likelihood of negative consequences of childhood maltreatment. Negative consequences following childhood maltreatment can be prevented or moderated if protective factors are provided in time. Future research needs to address the conceptualization issue of resilience. 
This is a post-peer-review, pre-copyedit version of an article published in 'Social Indicators Research'. The final authenticated version is available online at: https://doi.org/10.1007/s11205-015-0941-6. The following terms of use apply: https://www.sprin

Conclusions Public and population mental health preventions should focus on early childhood and apply preventive strategies as early as possible. Cost-effective studies should be considered in the evaluation of resilience prevention program.

Keywords Child abuse; Depression; Anxiety disorders; Resilience; Protective factors 
This is a post-peer-review, pre-copyedit version of an article published in 'Social Indicators Research'. The final authenticated version is available online at: https://doi.org/10.1007/s11205-015-0941-6. The following terms of use apply: https://www.sprin

\section{Introduction}

Child maltreatment is internationally considered as a serious public health, human rights, legal and social issue [1]. Every year it is estimated that millions of children are abused and neglected [2]. International studies revealed that an estimated 20\% of women and 5\% to $10 \%$ of men reported being sexually abused during childhood, and $25 \%$ to $50 \%$ of all children reported being physically abused [3].

Child abuse, including physical abuse, sexual abuse and emotional abuse, and neglect progressively contribute to compromised adaptation in a number of developmental domains and issues central to a successful progression to adulthood. These developmental failures pose significant risk for psychopathology [4-7]. The sequelae accompanying child maltreatment not only cause adverse consequences during childhood, but also initiate a negative developmental trajectory that lasts through the lifetime [8]. However, despite the increase risk of psychopathology, research indicates that some abused individuals retain normal levels of functioning [9]. This dynamic developmental process encompassing the attainment of positive adaptation within the context of significant adversity is referred as resilience [10].

Even though many studies had been carried on to research the conceptualization of resilience, which has been measured by various approaches, most often using various scales, no consensus on an operational definition has been reached [11]. In light of previous studies, resilience can be defined as adaptive functioning and/or absence of psychopathological symptoms [10,12]. Protective factors are individual and/or social characteristics that can be modified, or altered individual's response to stressors that 
This is a post-peer-review, pre-copyedit version of an article published in 'Social Indicators Research'. The final authenticated version is available online at: https://doi.org/10.1007/s11205-015-0941-6. The following terms of use apply: https://www.sprin

predisposes individual to a maladaptive outcome [13]. Research on resilience and its associated protective factors is needed to guide the development of treatment and prevention programs.

To our knowledge, there are very few traditional/ narrative reviews published on resilience and child maltreatment in general [2,14-16], one literature review in French looked at protective factors following child sexual abuse and summarized that social support and cognitive coping were related to the recovery but the extent of their contribution was unstated [17], and another systematic review looked at resilience in survivors of child sexual abuse and reached a similar conclusion that family and social support played the key role in resilience [10]. Previous traditional reviews summarized protective factors associated with sexual abuse, but did not systematically synthesize the evidence for other subtypes of childhood adversities. The research in this area has substantially increased in recent years. Furthermore, these newer studies have found that common and unique negative psychological and negative consequences are related to specific subtypes of childhood maltreatment. It is important to have an overview of resilience and protective factors associated with better life outcomes following the exposure of childhood maltreatment in general and specific subtypes of maltreatment. In addition, the timing of abuse experience in childhood is critical for development and is closely related to occurrence of psychological problems in the adulthood. However, there is no systematic review that has been conducted to explore different sets of adaptive factors related to the timing of childhood maltreatment.

Given the large number of original studies that have been published in the recent years, a systematic review comprehensively synthesizing protective factors following 
This is a post-peer-review, pre-copyedit version of an article published in 'Social Indicators Research'. The final authenticated version is available online at: https://doi.org/10.1007/s11205-015-0941-6. The following terms of use apply: https://www.sprin

child maltreatment is needed. This systematic review had three objectives. Firstly, we provided an overview of protective factors and resilience associated with better life outcomes against child maltreatment. Secondly, we compared the outcomes and protective factors at different developmental stages (children, adolescents, and adults) and taking the issue of age specificity of resilience into account. Thirdly, we rated the quality of selected studies according to a quality assessment checklist and reviewed methodological issues in the discussion section.

This review provides guidance for the implementation of programs and services designed to prevent and reduce childhood adversities and to treat their sequelae, and in turn, to decrease incidence and prevalence of psychopathological problems and promote protective factors related to resilience in our communities. Research into resilience in the aftermath of child maltreatment is valuable, empirical studies suggest that resilience may act as a protective mechanism thwarting the development of mental health problems. Resilience refers to the ability to employ a collection of protective factors to return to or maintain positive mental health following the experience of disadvantage or adversity. This review aids in building an evidence base for effective resilience-focused interventions and in doing so provides an opportunity to better inform the development of interventions to potentially prevent mental health problems in child and adolescent populations.

\section{Methods}


This is a post-peer-review, pre-copyedit version of an article published in 'Social Indicators Research'. The final authenticated version is available online at: https://doi.org/10.1007/s11205-015-0941-6. The following terms of use apply: https://www.sprin

The process and reporting of results systematic review were guided by the PRISMA guidelines, 2009 revision [18].

\section{Search strategy for identification of studies}

To ensure a thorough and systematic review of the literature, two methods were used to retrieve all relevant studies. Firstly, we conducted computerized searches in the PubMed, PsychINFO, EMBASE, Medline, and Cochrane Library databases for published articles up to October 31, 2017. To get the maximum number of relevant citations, we used the following search strings: 'child' AND (abus* OR maltreat* OR neglect OR abandon* OR illtreat* OR ill-treat* OR mal-treat* OR advers* OR trauma* OR ACE*) AND (resilience OR resiliency OR protective OR adaptive OR Resilient)' as the keywords for study retrieval. Secondly, a snowball technique was applied whereby the reference lists of selected original and review articles on relevant topic, and the gray literatures were screened.

\section{Inclusion criteria}

All suitable articles were evaluated with regards to their internal validity and the following six inclusion criteria: 1) had a cohort, or case-control, or cross-sectional study design; 2) used a clear diagnosis criteria/ questionnaire for absence of psychopathology, adaptive functioning, or other positive outcomes; 3) gave clear information on the assessment of childhood maltreatment (e.g. subtypes of maltreatment, age when abused, length of abuse, parental mood, etc.) or adverse childhood experience. The information 
This is a post-peer-review, pre-copyedit version of an article published in 'Social Indicators Research'. The final authenticated version is available online at: https://doi.org/10.1007/s11205-015-0941-6. The following terms of use apply: https://www.sprin

on abuse was either from written documents or a standard scale or questionnaire; 4)

provided a statistical indicator (i.e. relative risk) or original data to estimate the relationship between child abuse and positive outcomes; 5) controlled potential confounders by using statistical adjustment in the analysis or matching in the study design; and, 6) published in English.

\section{Exclusion criteria}

Articles were excluded from this review if they 1) were case reports, or qualitative studies or narrative reviews; 2) did not provide detailed information on childhood abuse or resilient outcome or protective factors.

\section{Selection of studies}

Two authors (XM \& CD) independently screened the titles. Then, they retrieved abstracts of all studies that met the inclusion criteria. If two review authors deem an article to be irrelevant, it was discarded, and vice versa. Inconsistencies in interpretation were resolved through a group of discussions with other coauthors. Endnote and RefWorks were used as bibliographic software. Figure 1 presents the process of studies selection.

\section{Data extraction and management}

Data on author, publication year, country, sample size, cohort, study design, resilience and protective factors, measures of protective and resilient factors, 
This is a post-peer-review, pre-copyedit version of an article published in 'Social Indicators Research'. The final authenticated version is available online at: https://doi.org/10.1007/s11205-015-0941-6. The following terms of use apply: https://www.sprin

measurements of abuse, type of abuse, outcomes, measurements of outcomes, major findings were extracted independently by the two authors. If there were multiple reports of a single study, they were coded into a single record in the data extraction form. The latest published report that we found was extracted first and then additional reports were used to fill the gaps, if any. Study authors were contacted for clarification, if necessary. Any disagreements among review authors were discussed. Table 1 presents a summary of all eligible articles.

\section{Data synthesis}

We assessed the heterogeneity of selected studies for the following study characteristics, including study subjects, measurements on child maltreatment, resilience, protective factors, resilient outcomes, and statistical analyses. The large amount of heterogeneity found for the above characteristics precluded the use of meta-analysis in this review. Differences in study characteristics significantly violate the underlying assumption of random-effects models, which assume that different studies are drawn from a normal distribution [19]. Consequently, as recommended, a qualitative approach was applied to further explore the overview of resilience after child maltreatment in general and in subtypes of maltreatment based on the primary objectives of the selected studies.

A quality assessment checklist for each study was also developed based on key study characteristics (Appendix 1). There were ten characteristics explored (total score=10), with the assumption of each characteristic equally contributed to study quality. 
This is a post-peer-review, pre-copyedit version of an article published in 'Social Indicators Research'. The final authenticated version is available online at: https://doi.org/10.1007/s11205-015-0941-6. The following terms of use apply: https://www.sprin

\section{Results}

\section{The summary of the search}

The initial search produced 13,675 titles, from which 5,808 abstracts were reviewed, and 247 articles were fully retrieved for full evaluation. A total of 85 articles met the eligibility criteria. The average score of study quality for selected articles was 5.80 (ranged from 3 to 9). A total of 43 studies (51\%) had above-average quality. Appendix 2 provides the full list of selected articles, which are listed according to the order of individual reference in the Table 1. This review covers 194,876 study participants, with the sample size ranged from 51 to 47,869 (median sample size $=260$ ). The selected 85 studies used a wide range of conceptualization for resilience, including adaptive functioning, social and emotional adjustment, family functioning, college adjustment, life satisfaction, maltreatment perpetration, academic achievement, re-traumatization, intergenerational abuse, adolescent adjustment, perceived competence, adult relationships, and absence of psychopathology.

In general, two groups of studies were identified among 85 selected studies. Group I consisted of 11 studies that examined whether resilience could protect against the negative consequence of early childhood maltreatment. Resilience was measured by a standard or structured interview or questionnaire. Most studies used the ConnorDavidson Resilience scale (CD-RISC) to assess the level of resilience. These studies universally supported that resilience reduced the risk of lifetime alcohol and illicit drug 
This is a post-peer-review, pre-copyedit version of an article published in 'Social Indicators Research'. The final authenticated version is available online at: https://doi.org/10.1007/s11205-015-0941-6. The following terms of use apply: https://www.sprin

use, PTSD, depression, interpersonal and physical distress, and had more adaptive functioning. Because these studies targeted different outcomes (mostly absence of psychopathology), and used different measurements to measure the exposure of child maltreatment, resilience and outcomes, all these inconsistences introduce a high level of heterogeneity across studies. Therefore we chose to present the results in Table 1.

Group II (75 studies) summarized the findings on what protective factors were associated with positive outcomes compared to those without these protective factors among people with the history of childhood maltreatment. There were several protective factors being examined for their contributions in multiple outcomes. We summarized research findings in subgroups according to the specific outcomes researched. In addition, Figure 2 shows the detailed information on the number of studies focused on individual protective factors. Notably, several studies explored multiple outcomes and protective factors. The most frequently studied factors were social support, family cohesion, coping skills and self-control.

Table 1 provides a summary of selected articles and shows details on the attributes of the studies contained in each group and subgroup. The following review summarizes the findings according to outcomes.

\section{Resilience reduced the risk of health problems and increases adaptive functioning} (11/85)- Group I

Generally, most of the studies (9/11) used cohorts with any kind of childhood abuse, except one studied sexual abuse and another psychological abuse. A variety of 
This is a post-peer-review, pre-copyedit version of an article published in 'Social Indicators Research'. The final authenticated version is available online at: https://doi.org/10.1007/s11205-015-0941-6. The following terms of use apply: https://www.sprin

observational study designs (11/11) were used. Most had well-accepted measurements for resilience and abuse (9/11), covered children, adolescents, and adults, and examined the role of resilience in health outcomes and/or adaptive functioning. The major heterogeneity was in the measurement of various outcomes explored. However, most of studies (8/11) had an above-average score according to the study quality assessment list.

Consistently, resilient children, adolescents and adults were found to have a lower risk of developing mental health problems (depression, PTSD, alcohol abuse, illicit drug use, interpersonal and psychological distress) and a better functioning (i.e. better parenting skills). Subsequent to childhood maltreatment, resilience was associated with a better life outcome from childhood to adulthood.

Relationships between protective factors and absence of psychopathology (44/85) subgroup IIa

Half of studies $(44 / 85,52 \%)$ used absence of psychopathology to indicate resilience against the history of childhood maltreatment. Among these studies, psychopathology was broadly defined, including a wide range of psychiatric disorders, i.e. depression, anxiety, PTSD, illicit drug use, alcohol use, suicide attempts and ideation, psychological distress, psychosis, and internalizing and externalizing problems. Different questionnaires and scales were used to access the presence of psychopathology and its related protective factors. In order to better present these factors, we categorized these factors into three levels, including individual factors, family and peers factors, and community/ society factors (see Table 2). Although different mental health problems and protective factors were studied, these studies consistently found negative relationships between protective 
This is a post-peer-review, pre-copyedit version of an article published in 'Social Indicators Research'. The final authenticated version is available online at: https://doi.org/10.1007/s11205-015-0941-6. The following terms of use apply: https://www.sprin

factors and psychopathology. These protective factors reduced the risk of individuals with a history of childhood maltreatment having mental health problems across all age groups. The study quality of these studies ranged from low to high, but most had an average study quality.

Relationships between protective factors and school functioning (4/85) - subgroup IIb

There are four studies originally from USA focused on school functioning among children, adolescents, and young adults. Consistently, these studies found that individual attributes (intelligence, social skills), family/peer factors (family and peer context, relatedness with mother), and societal factors (social and emotional resources) played an important role in promoting better school functioning. Protective factors during the early life before adulthood were associated with better academic performances. The study quality of these studies ranged from low to middle.

Relationships between protective factors and adaptive functioning (capacity of handling everyday demands and independence compared to people with the similar background) (12/85) - subgroup IIc

This subgroup included all three levels of protective factors: individual factors (intelligence, personality, personal control, children social information processing, cognitive ability, well-adjusted temperament, social deprivation, positive self-esteem, ego resilience, ego-over control, social adjustment, physical self-efficacy); family/ peers factors (parenting, stable living situation, supportive partner or spouse, maternal 
This is a post-peer-review, pre-copyedit version of an article published in 'Social Indicators Research'. The final authenticated version is available online at: https://doi.org/10.1007/s11205-015-0941-6. The following terms of use apply: https://www.sprin

warmth, maternal mental health problems, parental antisocial personality, parental substance use problems, adult domestic violence, sibling warmth, sibling conflict, relatedness to mother); and societal factors (neighborhood advantage, crime rate, social cohesion, and informal social control in neighborhood). Likewise, the presence of these factors predicted better functioning (from childhood to late adulthood) among those who had a history of childhood abuse, compared to those without these protective factors. Notably, there were a higher proportion of studies on physical abuse (4/12). All these studies were from USA. The study quality of these studies ranged from low to high, and most of them were of high quality.

Relationships between protective factors and interpersonal relationships (3/85) subgroup IId

Three USA studies used children and female adult cohorts to explore how maternal factors (attachment and care) and social support influenced on later-on adulthood interpersonal relationships. They found that these positive maternal factors led to better interpersonal relationships. The study quality of this subgroup was mixed.

\section{Relationships between protective factors and traumatization (7/85) - subgroup IIe}

These studies used cohorts of children, adolescents and young adults and found resilient survivors of childhood maltreatment had a reduced risk of traumatization either to themselves or others. Safe stable, nurturing relationships, mentorship, emotional support, secure attachment, locus of control, positive coping skills, family cohesion, and 
This is a post-peer-review, pre-copyedit version of an article published in 'Social Indicators Research'. The final authenticated version is available online at: https://doi.org/10.1007/s11205-015-0941-6. The following terms of use apply: https://www.sprin

number of years living with their biological mother were associated with a reduced risk of re-traumatization and intergenerational abuse. The study quality of these studies was low to middle.

Relationships between protective factors and life satisfaction, psychological wellbeing, perceived competence, and self-concept (7/85) - subgroup IIf

This subgroup used cohorts of adolescents and young adults. These studies found that resilient survivors of childhood maltreatment were more extraverted, agreeable, conscientious, had good family cohesion, having supportive relationships, and were able to find positive meaning in the trauma, compared to their peers. Most of the protective factors examined in this subgroup of studies were individual factors (personality, sense of family coherence, sense of school membership, ego identity, education and income level, and coping skills). One study also examined the role of family characteristics in evaluation of psychological wellbeing. The study quality of these studies was generally lower than average.

Relationships between protective factors and aggressive behavior (4/85) - subgroup IIg

Four USA studies studied cohorts of children, adolescents and young adults consistently found that sensitive parenting and social support from family and friends as well as living in a protective neighborhood predicted less aggressive behavior. The study quality of these studies was very mixed, ranging from low to high. 
This is a post-peer-review, pre-copyedit version of an article published in 'Social Indicators Research'. The final authenticated version is available online at: https://doi.org/10.1007/s11205-015-0941-6. The following terms of use apply: https://www.sprin

A summary of protective factors identified across selected studies

We summarized all the protective factors based on different subtypes of childhood maltreatment. Table 3 presents the overview of protective factors associated with different subtypes of childhood maltreatment. Clearly, there is a lack of research on emotional abuse and even less on neglect. Although most of studies generally used questionnaires to evaluate the presence and severity of maltreatment without further grouping into subtypes of maltreatment, there have been a lot of studies conducted focusing on populations with the history of physical and sexual abuse. All protective factors were further grouped into individual, familial and societal factors. Generally, the majority of studies focused on individual attributes, for instance, personality factors, and familial factors, with the emphasis on early childhood environmental factors. There were a large number of individual and familial protective factors associated with better health and wellbeing across different subtypes of maltreatment.

\section{Discussion}

To the best of our knowledge, this is the first comprehensive review to systematically synthesize relationships between resilience and its associated protective factors among people with a history of childhood maltreatment. In general, we found that 1) resilience was associated with a better life, in terms of reducing the risk of psychopathology, decreasing the likelihood of traumatization, increasing the level of perceived psychological wellbeing, and developing more adaptive skills; 2) protective factors at 
This is a post-peer-review, pre-copyedit version of an article published in 'Social Indicators Research'. The final authenticated version is available online at: https://doi.org/10.1007/s11205-015-0941-6. The following terms of use apply: https://www.sprin

individual, familial, and societal levels predicted subsequent resilience against negative consequences of childhood maltreatment; 3) although the conceptualization of resilience following childhood maltreatment, and measurements of study outcomes and protective factors have been varied, it is clear that protective factors at individual, familial and societal levels played a significant role in promoting psychological wellbeing and reduced the risk of negative consequences of childhood maltreatment; and, 4) there has been a lack of research in the field of resilience following emotional abuse, and even more scare for neglect, compared to the ample number studies concerning maltreatment in general and following physical and sexual abuse.

\section{How and why resilience and its factors work?}

Studies have proved that child maltreatment constitutes a strong environmental hazard to children's adaptive functioning [20-22]. Negative experiences have been recognized as continuing toxic conditions whereby people with the experience of maltreatment would then be exposed to further chronic and severe stress [23]. Negative experiences significantly increase the risk of development of psychopathology across the lifespan [24], the intergenerational transmission of maltreatment, and re-traumatization [25]. The body has to pay a biological price when faced with repeated major stressors (i.e. child maltreatment) and the resultant physiological sequelae of chronic exposure to heightened and sustained neural and neuroendocrine responsiveness [26]. Therefore, factors that reduce the allostatic load could prevent or intervene against the negative consequences of childhood maltreatment. They are many factors, which can decrease the allostatic load at individual, familial and societal levels. 
This is a post-peer-review, pre-copyedit version of an article published in 'Social Indicators Research'. The final authenticated version is available online at: https://doi.org/10.1007/s11205-015-0941-6. The following terms of use apply: https://www.sprin

Individuals who begin on the same developmental trajectory may exhibit very different patterns of adaption and maladaptation. When confronted with childhood maltreatment, some may exhibit adaptive functioning across the rest of lifespan and others not. The pathway to adaptive functioning can be very complicated following different paths. It involves the interplay between biological and psychological organization, current experiences and environments, the timing of adversity and experience, and family and community context. It is important to recognize and triage major determinants associated with resilience in the face of experiencing severe stressors [27].

\section{Which protective factors contribute to adaptive functioning?}

Due to the wide variation in measurements of child maltreatment and outcomes and different study participants, it is difficult to apply a simple method comparing primary findings across studies. However, we found that the family and/or peers factors, for example, maternal care, close mother-child relationship and friendship and societal factors (i.e. social support) had shown consistent protection in better life and adaptive functioning. In light of gender specific findings of prevalent subtypes of child abuse, studies have been conducted to especially explore protective factors for individual subtypes of child maltreatment among participants of a particular gender. A list of sexand gender-specific determinants has been reported [28-39], and most of these studies were primarily interested in resilience associated sexual abuse among women and girls. Both familial and societal factors provide supportive environment and relationships that could facilitate adaptive responses, which reduce the allostatic load on stress response 
This is a post-peer-review, pre-copyedit version of an article published in 'Social Indicators Research'. The final authenticated version is available online at: https://doi.org/10.1007/s11205-015-0941-6. The following terms of use apply: https://www.sprin

system [23]. Notably, the protection of protective factors cannot last through the whole life, as it is a dynamic process balancing between resilience and allostatic load. Although none of the selected studies reported the "bounce back" phenomenon among formerly resilient individuals, previous literature did introduce resilience as a dynamic concept [40]. The absence of "bounce back" in the studies reviewed may be explained by the fact that all selected studies are cross-sectional or short-term longitudinal studies. Long-term longitudinal studies are required to observe the trajectory of resilience across various turning points across the lifespan.

It is noteworthy that different protective factors were identified among different age groups following with the exposure of childhood maltreatment. In general, early environmental factors, such as maternal care, relationship with mother at younger ages, etc. played a significant role across the lifespan, especially for early life. As children and youths grow up, more factors contributed to the protection, including both early life factors and time-point specific factors (such as school environmental factors, peer relationships, etc. for adolescents.). The protection of these factors in health and adaptive functioning dynamically change as an individual ages. Some factors become more distal and lose their dominant roles in their protection and other proximal factors become more important. In addition, the importance of protective factors is also influenced by the age of onset of maltreatment, which is critical for child development and the likelihood of psychological problems later on. We found that the earlier exposure of maltreatment the greater protection was needed from early environmental factors. This may be partially explained by the more vulnerable and sensitive period of neurodevelopment in early life. Also, later exposure of maltreatment in adolescents was associated with more familial 
This is a post-peer-review, pre-copyedit version of an article published in 'Social Indicators Research'. The final authenticated version is available online at: https://doi.org/10.1007/s11205-015-0941-6. The following terms of use apply: https://www.sprin

and societal factors (relatively proximal protective factors) to buffer the negative influence of maltreatment on health and adaptive functioning.

\section{Strengths \& limitations}

Although research on resilience of child maltreatment has been conducted for decades, only a few systematic reviews have been reported and even fewer had been conducted on selected types of child maltreatment for specific measures of adaptive functioning, i.e. a systematic review on sexual abuse and psychopathology [10]. This current review is one of few studies using a systematic approach to explore what protective factors are associated with resilience following childhood maltreatment across the life course. Furthermore, it provides synthesized results on the relationships between all kinds of childhood maltreatment and a full list of adaptive functioning. It offers an overview of resilience among people with a history of child maltreatment. There are a few limitations to note. Firstly, the conceptualization of resilience has evolved over the decades, and it has generally been understood as the achievement of adaptive functioning in the context of ongoing significant adversity, that poses a great challenge in synthesizing results from relevant studies, as it can introduce significant heterogeneity in the review. Secondly, the study quality of the selected studies varied a lot when considering study design, sample size, confounders, statistical analyses, and measurements of outcomes and exposures. The results of this review should be interpreted with caution. Thirdly, the identification of child maltreatment (and its subtypes) varied across studies. Among the selected studies, only a small proportion of them verified the status of child maltreatment by applying official records, whereas the 
This is a post-peer-review, pre-copyedit version of an article published in 'Social Indicators Research'. The final authenticated version is available online at: https://doi.org/10.1007/s11205-015-0941-6. The following terms of use apply: https://www.sprin

majority of studies used a set of survey questionnaires. It clearly introduces a significant heterogeneity in terms of measurement accuracy, abuse severity, and its impact. We found that findings from studies with official records were generally consistent with studies using questionnaires and scales. However, due to the limited number of studies with official records, the number of protective and resilient factors studied in these studies was limited. Fourthly, this review only studied the literature published in English. It is possible that this review does not capture those articles published in other languages. As most of the reviewed studies are from developed countries, there is an obvious need for studies carried out in developing countries. Lastly, due to the fact of inconsistent measurements of study characteristics (i.e. study outcomes, conceptualization of resilience, study populations, etc.), we did not, as recommended, perform a meta-analysis for selected studies, as biases would be introduced into the pooled results.

\section{Practical implications of this review}

Consistent with the literature, this review reinforces that the negative sequelae of childhood maltreatment may be prevented or moderated if protective factors are provided at the right time. Resilience is not "immutable". There are several sensitive periods or socalled "turning points" closely related to a dynamic process of functioning. They help either remaining in an adaptive or positive functioning trajectory despite adversity, or becoming maladaptive staying on a negative functioning trajectory.

From research perspectives, the conceptualization of resilience should include multiple domains, as the research in this area has expanded becoming more multidisciplinary and with composite scores being used more often to indicate the 
This is a post-peer-review, pre-copyedit version of an article published in 'Social Indicators Research'. The final authenticated version is available online at: https://doi.org/10.1007/s11205-015-0941-6. The following terms of use apply: https://www.sprin

competent functioning. In addition, not only the accuracy of maltreatment experience should be confirmed, but also some indicators of severity of maltreatment experience should be added into the data collection and analysis. If possible, official records or standardized questionnaires (or the two methods combined) should be employed. Longterm longitudinal studies are needed to investigate the trajectory of resilience across the lifespan in order to identify the sensitive periods or critical turning points. As we noted in this review, the majority of primary studies reviewed here are from USA (60/85), followed by UK (5/85), Canada (5/85), Germany (4/85), and other countries. Findings from developing countries are also important to help understand a complete picture of resilience and child maltreatment.

From population and public health perspectives, early childhood is crucial to prevention and intervention efforts for those confronted with child adversity. Supportive environment (from family, school, to society) should be included in the target lists for vulnerable groups, as they have consistently been confirmed to be protective. Although the potential benefits of health promotion at any age cannot be underestimated, the emphasis should be given to an early age, if possible. Prevention studies (including costeffective studies) are needed to evaluate the efficacy and effectiveness of these prevention strategies among the high-risk population groups.

\section{Conclusions}

Overall, we found that a scientific consensus is emerging that protective factors were associated with a wide range of adaptive functioning that guard against the negative sequelae of child maltreatment. Individual, familial and societal factors were linked with 
This is a post-peer-review, pre-copyedit version of an article published in 'Social Indicators Research'. The final authenticated version is available online at: https://doi.org/10.1007/s11205-015-0941-6. The following terms of use apply: https://www.sprin

resilience, and the most consistent findings related to familial factors. Studies with the following characteristics are still warranted: long-term longitudinal study design, large sample size, from developing countries, using a multi-domain definition for resilience and standardized measurements of child maltreatment, taking multiple covariates (for instance, neighborhood disadvantages, childhood economic status, critical life events, age of onset of maltreatment, etc.) into account in the data analysis plan. Health prevention and promotion could significantly benefit from advances in neuroscience and biology of stress system, as they can help to disentangle the complexity of biological mechanisms underlying the resilience-abuse relationship. These disciplinary perspectives should be integrated into resilience research as a part of the agenda.

\section{Conflict of interests}

The authors declared no potential conflicts of interest with respect to the research, authorship, and/or publication of this article.

\section{Funding}

Dr. Meng received the start-up fund from Douglas Mental Health University Institute and a Scholar Award from the Fonds de recherche du Québec-Santé. This study was also supported by a Canadian Institute of Health Research grant (PJT-148845). 
This is a post-peer-review, pre-copyedit version of an article published in 'Social Indicators Research'. The final authenticated version is available online at: https://doi.org/10.1007/s11205-015-0941-6. The following terms of use apply: https://www.sprin

\section{References}

1. Butchart A, Harvey AP, Furniss T (2006) Preventing child maltreatment: a guide to taking action and generating evidence. Geneva $(\mathrm{CH})$ : World Health Organization and International Society for Prevention of Child Abuse and Neglect.

2. Afifi TO, Macmillan HL (2011) Resilience following child maltreatment: a review of protective factors. Can J Psychiatry 56 (5):266-272. doi: 10.1177/070674371105600505

3. WHO (2012) Media Centre: Child maltreatment. Geneva: World Health Organzation

4. Howe ML, Cicchetti D, Toth SL (2006) Children's basic memory processes, stress, and maltreatment. Dev Psychopathol 18 (3):759-769.

5. Ayoub CC, O'Connor E, Rappolt-Schlichtmann G, Fischer KW, Rogosch FA, Toth SL, Cicchetti $D$ (2006) Cognitive and emotional differences in young maltreated children: a translational application of dynamic skill theory. Dev Psychopathol 18 (3):679-706.

6. Kim J, Cicchetti D (2006) Longitudinal trajectories of self-system processes and depressive symptoms among maltreated and nonmaltreated children. Child Dev 77 (3):624-639. doi:10.1111/j.1467-8624.2006.00894.x

7. Li M, D'Arcy C, Meng X (2016) Maltreatment in childhood substantially increases the risk of adult depression and anxiety in prospective cohort studies: systematic review, metaanalysis, and proportional attributable fractions. Psychol Med 46 (4):717-730. doi:10.1017/S0033291715002743

8. Masten AS, Cicchetti D (2010) Developmental cascades. Dev Psychopathol 22 (3):491-495. doi:10.1017/S0954579410000222

9. Kendall-Tackett KA, Williams LM, Finkelhor D (1993) Impact of sexual abuse on children: a review and synthesis of recent empirical studies. Psychol Bull 113 (1):164-180.

10. Domhardt M, Munzer A, Fegert JM, Goldbeck L (2015) Resilience in Survivors of Child Sexual Abuse: A Systematic Review of the Literature. Trauma Violence Abuse 16 (4):476493. doi:10.1177/1524838014557288

11. Cicchetti $D$ (2010) Resilience under conditions of extreme stress: a multilevel perspective. World Psychiatry 9 (3):145-154.

12. Daigneault I, Hebert M, Tourigny M (2007) Personal and interpersonal characteristics related to resilient developmental pathways of sexually abused adolescents. Child Adolesc Psychiatr Clin N Am 16 (2):415-434, x. doi:10.1016/j.chc.2006.11.002

13. Rutter M (1985) Resilience in the face of adversity. Protective factors and resistance to psychiatric disorder. Br J Psychiatry 147:598-611.

14. Heller SS, Larrieu JA, D'Imperio R, Boris NW (1999) Research on resilience to child maltreatment: empirical considerations. Child Abuse Negl 23 (4):321-338.

15. Haskett ME, Nears K, Ward CS, McPherson AV (2006) Diversity in adjustment of maltreated children: factors associated with resilient functioning. Clin Psychol Rev 26 (6):796-812. doi:10.1016/j.cpr.2006.03.005

16. Herrmann D, Scherg H, Verres R, von Hagens C, Strowitzki T, Wischmann T (2011) Resilience in infertile couples acts as a protective factor against infertility-specific distress and impaired quality of life. J Assist Reprod Genet 28 (11):1111-1117. doi:10.1007/s10815-0119637-2

17. Dufour MH, Nadeau L, Bertrand K (2000) [Resilience factors in the victims of sexual abuse: state of affairs]. Child Abuse Negl 24 (6):781-797. 
This is a post-peer-review, pre-copyedit version of an article published in 'Social Indicators Research'. The final authenticated version is available online at: https://doi.org/10.1007/s11205-015-0941-6. The following terms of use apply: https://www.sprin

18. Moher D, Liberati A, Tetzlaff J, Altman DG, Group P (2009) Preferred reporting items for systematic reviews and meta-analyses: the PRISMA statement. BMJ 339:b2535. doi:10.1136/bmj.b2535

19. Higgins JP, Thompson SG, Spiegelhalter DJ (2009) A re-evaluation of random-effects metaanalysis. J R Stat Soc Ser A Stat Soc 172 (1):137-159. doi:10.1111/j.1467-985X.2008.00552.x

20. Cicchetti D, Toth SL (1995) A developmental psychopathology perspective on child abuse and neglect. J Am Acad Child Adolesc Psychiatry 34 (5):541-565. doi:10.1097/00004583199505000-00008

21. Cicchetti D (2013) Annual Research Review: Resilient functioning in maltreated children-past, present, and future perspectives. J Child Psychol Psychiatry 54 (4):402-422. doi:10.1111/j.1469-7610.2012.02608.x

22. Cicchetti D (2016) Socioemotional, Personality, and Biological Development: Illustrations from a Multilevel Developmental Psychopathology Perspective on Child Maltreatment. Annu Rev Psychol 67:187-211. doi:10.1146/annurev-psych-122414-033259

23. Shonkoff JP, Boyce WT, McEwen BS (2009) Neuroscience, molecular biology, and the childhood roots of health disparities: building a new framework for health promotion and disease prevention. JAMA 301 (21):2252-2259. doi:10.1001/jama.2009.754

24. Nanni V, Uher R, Danese A (2012) Childhood maltreatment predicts unfavorable course of illness and treatment outcome in depression: a meta-analysis. Am J Psychiatry 169 (2):141151. doi:10.1176/appi.ajp.2011.11020335

25. Trickett PK, Noll JG, Putnam FW (2011) The impact of sexual abuse on female development: lessons from a multigenerational, longitudinal research study. Dev Psychopathol 23 (2):453476. doi:10.1017/S0954579411000174

26. Ganzel BL, Morris PA, Wethington E (2010) Allostasis and the human brain: Integrating models of stress from the social and life sciences. Psychol Rev 117 (1):134-174. doi:10.1037/a0017773

27. Luthar SS, Cicchetti D, Becker B (2000) The construct of resilience: a critical evaluation and guidelines for future work. Child Dev 71 (3):543-562.

28. Edwards KM, Probst DR, Rodenhizer-Stampfli KA, Gidycz CA, Tansill EC (2014) Multiplicity of child maltreatment and biopsychosocial outcomes in young adulthood: the moderating role of resiliency characteristics among female survivors. Child Maltreat 19 (3-4):188-198. doi:10.1177/1077559514543354

29. Walsh K, Blaustein M, Knight WG, Spinazzola J, van der Kolk BA (2007) Resiliency factors in the relation between childhood sexual abuse and adulthood sexual assault in college-age women. J Child Sex Abus 16 (1):1-17. doi:10.1300/J070v16n01_01

30. Liang B, Williams LM, Siegel JA (2006) Relational outcomes of childhood sexual trauma in female survivors: a longitudinal study. J Interpers Violence 21 (1):42-57. doi:10.1177/0886260505281603

31. Banyard VL, Williams LM, Siegel JA (2002) Re-traumatization among adult women sexually abused in childhood: exploratory analyses in a prospective study. J Child Sex Abus 11 (3):1948.

32. Lam JN, Grossman FK (1997) Resiliency and adult adaptation in women with and without self-reported histories of childhood sexual abuse. J Trauma Stress 10 (2):175-196.

33. Wahab S, Tan SM, Marimuthu S, Razali R, Muhamad NA (2013) Young female survivors of sexual abuse in Malaysia and depression: what factors are associated with better outcome? Asia Pac Psychiatry 5 Suppl 1:95-102. doi:10.1111/appy.12051 
This is a post-peer-review, pre-copyedit version of an article published in 'Social Indicators Research'. The final authenticated version is available online at: https://doi.org/10.1007/s11205-015-0941-6. The following terms of use apply: https://www.sprin

34. Wilson L, Scarpa A (2014) Childhood abuse, perceived social support, and posttraumatic stress symptoms: a moderation model. Psychological trauma: Theory, Research, Practice, and Policy 6:512-518. doi: 10.1037/a0032635

35. Elkins J (2011) Developmental outcomes in a nationally representative sample of sexually abused boys: The moderating influence of family and peer context. Columbia University

36. Bruggen $L$ (2011) Romantic relationships in young women with a history of child maltreatment: examining the role of mentoring relationships as a protective factor. University of Victoria

37. Traina D (2008) Resilience in mothers who had been victims of physical child abuse: an exploration of the mediating effects of personality characteristics, coping skills, social support, and family characteristics. Seton Hall University

38. MCclure F, Chavez D, Agars M, Peacock M, Matosian A (2008) Resilience in sexually abused women: risk and protective factors. J Fam Viol 23:81-88. doi: 10.1007/s10896-007-9129-4

39. Moran PB, Eckenrode J (1992) Protective personality characteristics among adolescent victims of maltreatment. Child Abuse Negl 16 (5):743-754.

40. Rutter M (2012) Resilience as a dynamic concept. Dev Psychopathol 24 (2):335-344. doi:10.1017/S0954579412000028 
This is a post-peer-review, pre-copyedit version of an article published in 'Social Indicators Research'. The final authenticated version is available online at: https://doi.org/10.1007/s11205-015-0941-6. The following terms of use apply: https://www.sprin

\section{Appendix 1. A checklist for study quality assessment}

\begin{tabular}{|c|c|c|}
\hline Items & Quality Criteria & Quality Score \\
\hline 1 & Representativeness of the population & $\begin{array}{l}\text { Population-based representative }=1 ; \\
\text { Not representative, selected group, } \\
\text { volunteers, convenient samples, or no } \\
\text { description }=0\end{array}$ \\
\hline 2 & $\begin{array}{l}\text { Does the paper have a large sample size for } \\
\text { its study design? }\end{array}$ & $\begin{array}{l}\text { If the sample size }>100=1 \text {; otherwise } \\
=0\end{array}$ \\
\hline 3 & Application of longitudinal study design & Yes $=1 ;$ No $=0$ \\
\hline 4 & $\begin{array}{l}\text { Ascertainment of exposure to child } \\
\text { maltreatment }\end{array}$ & $\begin{array}{l}\text { Data on child abuse extracted from } \\
\text { official records }=1 ; \text { otherwise }=0\end{array}$ \\
\hline 5 & Assessment of child maltreatment & $\begin{array}{l}\text { Standard or structured interview or } \\
\text { questionnaire }=1 \text {, or selective } \\
\text { questions or no description }=0\end{array}$ \\
\hline 6 & Assessment of outcome & $\begin{array}{l}\text { Standard or structured interview or } \\
\text { questionnaire }=1 \text {; not systematic, not } \\
\text { specified, or self-reported }=0\end{array}$ \\
\hline 7 & $\begin{array}{l}\text { Application of a multi-domain } \\
\text { conceptualization of resilience }\end{array}$ & Yes $=1 ;$ No $=0$ \\
\hline 8 & $\begin{array}{l}\text { Demonstration that outcome of interest was } \\
\text { not present at start of study }\end{array}$ & $\mathrm{Yes}=1 ; \mathrm{No}=0$ \\
\hline 9 & Appropriate statistical analysis & Yes $=1 ; \mathrm{No}=0$ \\
\hline 10 & $\begin{array}{l}\text { Appropriate methods to control } \\
\text { confounding }\end{array}$ & $\begin{array}{l}\text { Yes (multivariable adjustments in } \\
\text { models) }=1 \text {; No (univariate analysis } \\
\text { or controls for age/sex only) }=0\end{array}$ \\
\hline
\end{tabular}


This is a post-peer-review, pre-copyedit version of an article published in 'Social Indicators Research'. The final authenticated version is available online at: https://doi.org/10.1007/s11205-015-0941-6. The following terms of use apply: https://www.sprin

Appendix 2. Articles selected in this review

\section{Group I}

\section{Beutel, M.E., Tibubos, A.N., Klein, E., Schmutzer, G., Reiner, I., Kocalevent, R-D.\&} Brahler, E. (2017). Childhood adversities and distress - The role of resilience in a representative sample. PloS One doi.org/10.1371/journal.pone.0173826.

Kim, H., Kim, S.A. \& Kong, S. (2017). Resilience mediates impact of some childhood maltreatment on post-traumatic stress symptoms in conscripted marines in the Republic of Korea. Res Nurs Health 40, 51-62.

Tlapek, S.M., Auslander, W. Edmond, T., Gerke, D., Schrag, R.V. \& Threlfall, J. (2017). The moderating role of resiliency on the negative effects of childhood abuse for adolescent girls involved in child welfare. Children and Youth Services Review 73, 437-44.

Arslan, G. (2016). Psychological maltreatment, emotional and behavioral problems in adolescents: The mediating role of resilience and self-esteem. Child Abuse Negl 52, 200-9.

Sexton, M. B., Hamilton, L., McGinnis, E. W., Rosenblum, K. L. \& Muzik, M. (2015). The roles of resilience and childhood trauma history: main and moderating effects on postpartum maternal mental health and functioning. $J$ Affect Disord 174, 562-8.

Wingo, A. P., Ressler, K. J. \& Bradley, B. (2014). Resilience characteristics mitigate tendency for harmful alcohol and illicit drug use in adults with a history of childhood abuse: a crosssectional study of 2024 inner-city men and women. J Psychiatr Res 51, 93-9.

Edwards, K. M., Probst, D. R., Rodenhizer-Stampfli, K. A., Gidycz, C. A. \& Tansill, E. C. (2014). Multiplicity of child maltreatment and biopsychosocial outcomes in young adulthood: the moderating role of resiliency characteristics among female survivors. Child Maltreat 19, 188-98.

Schulz, A., Becker, M., Van der Auwera, S., Barnow, S., Appel, K., Mahler, J., Schmidt, C. O., John, U., Freyberger, H. J. \& Grabe, H. J. (2014). The impact of childhood trauma on depression: does resilience matter? Population-based results from the Study of Health in Pomerania. J Psychosom Res 77, 97-103.

Wingo, A. P., Wrenn, G., Pelletier, T., Gutman, A. R., Bradley, B. \& Ressler, K. J. (2010). Moderating effects of resilience on depression in individuals with a history of childhood abuse or trauma exposure. J Affect Disord 126, 411-4.

Graham-Bermann, S. A., Gruber, G., Howell, K. H. \& Girz, L. (2009). Factors discriminating among profiles of resilience and psychopathology in children exposed to intimate partner violence (IPV). Child Abuse Negl 33, 648-60. 
This is a post-peer-review, pre-copyedit version of an article published in 'Social Indicators Research'. The final authenticated version is available online at: https://doi.org/10.1007/s11205-015-0941-6. The following terms of use apply: https://www.sprin

Kaufman, J., Yang, B. Z., Douglas-Palumberi, H., Houshyar, S., Lipschitz, D., Krystal, J. H. \& Gelernter, J. (2004). Social supports and serotonin transporter gene moderate depression in maltreated children. Proc Natl Acad Sci US A 101, 17316-21.

\section{Group II}

Baytunca, M.B., Ata, E., Ozbaran, B., Kaya, A., Kose, S., Aktas, E.O., Aydin, R., Guney, S., Yuncu, Z., Erermis, S., Bildik, T \& Aydin, C. (2017). Childhood sexual abuse and supportive factors. Pediatr Int 59, 10-5.

Miller-Graff, L.E., Howell, K.H., Martinez-Torteya, C. \& Grein, K. (2017). Direct and indirect effects of maltreatment and social support on children's social competence across reporters. Child Psychiatry Hum Dev 48, 741-53.

Lind, M.J., Brown, R.C., Sheerin, C.M., York, T.P., Myers, J.M., Kendler, K.S. \& Amstadter, A.B. (2017). Does parenting influence the enduring impact of severe childhood sexual abuse on psychiatric resilience in adulthood? Child Psychiatry Hum Dev doi: 10.1007/s10578-017-0727-y.

Mohr., D. \& Rosen, L.A. (2017). The impact of protective factors on posttraumatic growth for college student survivors of childhood maltreatment. J Aggress Maltreatment Trauma 26, 756-71.

Go, M., Chu, C.M., Barlas, J. \& Chng, G.S. (2017). The role of strengths in anger and conduct problems in maltreated adolescents. Child Abuse Negl 67, 22-31.

Oshri, A., Topple, T.A. \& Carlson, M.W. (2017). Positive youth development and resilience: Growth patterns of social skills among youth investigated for maltreatment. Child Dev 88, 1087-99.

Shafa, Vanessa. (2016). Family relationship factors and their effects on resilience in adolescents maltreated by caregivers. Alliant International University.

Hardner, K., Wolf, M.R. \& Rinfrette, E.S. (2017). Examining the relationship between higher educational attainment, trauma symptoms, and internalizing behaviors in child sexual abuse survivors. Child Abuse Negl http://dx.doi.org/10.1016/j.chiabu.2017.10.007.

Yoon, S., Tebben, E \& Lee, G. (2017). Early childhood aggression among child welfare involved children: The interplay between the type of child maltreatment and ecological protective factors. Child Youth Serv Rev 81, 72-80.

Kaye-Tzadok, A \& Davidson-Arad, B. (2017). The contribution of cognitive strategies to the resilience of women survivors of childhood sexual abuse and non-abused women. Violence Against Women 23, 993-1015.

Schury, K., Zimmermann, J., Umlauft, M., Hulbert, A.L. Guendel, H., Ziegenhain, U. \& Kolassa, I-T. (2017). Childhood maltreatment, postnatal distress and the protective role of social support. Child Abuse Negl 67, 228-39. 
This is a post-peer-review, pre-copyedit version of an article published in 'Social Indicators Research'. The final authenticated version is available online at: https://doi.org/10.1007/s11205-015-0941-6. The following terms of use apply: https://www.sprin

Daigneault, I., Dion, J., Hebert, M. \& Bourgeois, C. (2016). Mindfulness as mediator and moderator of post-traumatic symptomatology in adolescence following childhood sexual abuse or assault. Mindfulness 7, 1306-15.

Afifi, T., MacMillan, H.L., Taillieu, T., Turner, S., Cheung, K., Sareen, J. \& Boyle, M.H. (2016). Individual- and relationship-level factors related to better mental health outcomes following child abuse: Results from a nationally representative Canadian sample. Can $J$ Psychiatry 61, 776-88.

Arslan, G. (2016). Psychological maltreatment, emotional and behavioral

problems in adolescents: The mediating role of resilience and self-esteem. Child Abuse Negl 52, 200-9.

Hillmann, K., Neukel, C., Hagemann, D., Herpertz, S.C. \& Bertsch, K. (2016). Resilience factors in women with severe early-life maltreatment. Psychopathology 49, 261-8.

Taubner, S., Zimmermann, L., Ramberg, A. \& Schroder, P. (2017). Mentalization mediates the relationship between early maltreatment and potential for violence in adolescence. Psychopathology 49, 236-46.

Dion, J., Matte-Gagne, C., Daigneault, I., Blackburn, M-E., Hebert, M. McDuff, P., Auclair, J., Veillette, S. \& Perron, M. (2016). A proposective study of the impact of child maltreatment and friend support on psychological distress trajectory: From adolescence to emerging adulthood. J Affect Disord 189, 336-43.

Cleary, S.E. (2016). Pathways from childhood abuse to positive adapation: The moderating roles of social support and coping style. University of Denver.

Muzik, M., Umarji, R., Sexton, M.B. \& Davis, M.T. (2017). Family social support modifies the relationships between childhood maltreatment severity, economic adversity and postpartum depressive symptoms. Matern Child Health J 21, 1018-25.

Aydin, B., Akbas, S., Turla, A. \& Dundar, C. (2016). Depression and post-traumatic stress disorder in child victims of sexual abuse: perceived social support as a protection factor. Nord J Psychiatry 70, 418-23.

Henry, K. L., Thornberry, T. P. \& Lee, R. D. (2015). The Protective Effects of Intimate Partner Relationships on Depressive Symptomatology Among Adult Parents Maltreated as Children. J Adolesc Health 57, 150-6.

Gayer-Anderson, C., Fisher, H. L., Fearon, P., Hutchinson, G., Morgan, K., Dazzan, P., Boydell, J., Doody, G. A., Jones, P. B., Murray, R. M., Craig, T. K. \& Morgan, C. (2015). Gender differences in the association between childhood physical and sexual abuse, social support and psychosis. Soc Psychiatry Psychiatr Epidemiol 50, 1489-500.

Manning, L. G., Davies, P. T. \& Cicchetti, D. (2014). Interparental violence and childhood adjustment: how and why maternal sensitivity is a protective factor. Child Dev 85, 2263-78.

Maples, L., Park, S., Nolen, J. \& Rosen, L. (2014). Resilience to childhood abuse and neglect in college students. Journal of Aggression, Maltreatment \& Trauma 23, 1001-1019. 
This is a post-peer-review, pre-copyedit version of an article published in 'Social Indicators Research'. The final authenticated version is available online at: https://doi.org/10.1007/s11205-015-0941-6. The following terms of use apply: https://www.sprin

Lowell, A., Renk, K. \& Adgate, A. H. (2014). The role of attachment in the relationship between child maltreatment and later emotional and behavioral functioning. Child Abuse Negl 38, 1436-49.

Sperry, D \& Widom, C.S. (2013). Child abuse and neglect, social support, and psychopathology in adulthood: A prospective investigation. Child Abuse Negl 37, 415-25.

Hengartner, M. P., Muller, M., Rodgers, S., Rossler, W. \& Ajdacic-Gross, V. (2013). Can protective factors moderate the detrimental effects of child maltreatment on personality functioning? J Psychiatr Res 47, 1180-6.

Wahab, S., Tan, S. M., Marimuthu, S., Razali, R. \& Muhamad, N. A. (2013). Young female survivors of sexual abuse in Malaysia and depression: what factors are associated with better outcome? Asia Pac Psychiatry 5 Suppl 1, 95-102.

Wilson, L. \& Scarpa, A. (2014). Childhood abuse, perceived social support, and posttraumatic stress symptoms: a moderation model. Psychological trauma: Theory, Research, Practice, and Policy 6, 512-518.

Folger, S. F. \& Wright, M. O. (2013). Altering risk following child maltreatment: Family and friend support as protective factors. J Fam Viol 28, 325-337.

Whitelock, C., Lamb, M. \& Rentfrow, P. (2013). Overcoming trauma: Psychological and demographic characteristics of child sexual abuse surviors in adulthood. Clinical psychological science 1, 351-362.

Thornberry, T. P., Henry, K. L., Smith, C. A., Ireland, T. O., Greenman, S. J. \& Lee, R. D. (2013). Breaking the cycle of maltreatment: the role of safe, stable, and nurturing relationships. J Adolesc Health 53, S25-31.

Kim-Spoon, J., Haskett, M. E., Longo, G. S. \& Nice, R. (2012). Longitudinal study of selfregulation, positive parenting, and adjustment problems among physically abused children. Child Abuse Negl 36, 95-107.

Williams, J. \& Nelson-Gardell, D. (2012). Predicting resilience in sexually abused adolescents. Child Abuse Negl 36, 53-63.

Ng, R. M., Bhugra, D., McManus, F. \& Fennell, M. (2011). Filial piety as a protective factor for depression in survivors of childhood abuse. Int Rev Psychiatry 23, 100-12.

Elkins, J. (2011). Developmental outcomes in a nationally representative sample of sexually abused boys: The moderating influence of family and peer context. Columbia University.

Coohey, C., Renner, L. M., Hua, L., Zhang, Y. J. \& Whitney, S. D. (2011). Academic achievement despite child maltreatment: a longitudinal study. Child Abuse Negl 35, 688-99.

Philippe, F., Laventure, S., Beaulieu-Pelletier, G., Lecours, S. \& Lekes, N. (2011). Ecoresiliency as a mediator between childhood trauma and psychological symptoms. Journal of Social and Clinical Psychology 30, 583-398.

Kim, J. \& Cicchetti, D. (2010). Longitudinal pathways linking child maltreatment, emotion regulation, peer relations, and psychopathology. J Child Psychol Psychiatry 51, 706-16. 
This is a post-peer-review, pre-copyedit version of an article published in 'Social Indicators Research'. The final authenticated version is available online at: https://doi.org/10.1007/s11205-015-0941-6. The following terms of use apply: https://www.sprin

Walter, K. H., Horsey, K. J., Palmieri, P. A. \& Hobfoll, S. E. (2010). The role of protective self-cognitions in the relationship between childhood trauma and later resource loss. $J$ Trauma Stress 23, 264-73.

Pitzer, L. M. \& Fingerman, K. L. (2010). Psychosocial resources and associations between childhood physical abuse and adult well-being. J Gerontol B Psychol Sci Soc Sci 65, 425-33.

Powers, A., Ressler, K. J. \& Bradley, R. G. (2009). The protective role of friendship on the effects of childhood abuse and depression. Depress Anxiety 26, 46-53.

Schultz, D., Tharp-Taylor, S., Haviland, A. \& Jaycox, L. (2009). The relationship between protective factors and outcomes for children investigated for maltreatment. Child Abuse Negl 33, 684-98.

Bruggen, L. (2009). Romantic Relationships in Young Women with a History of Child Maltreatment: Examining the Role of Mentoring Relationships as a Protective Factor. University of Victoria.

Reyes, C. J. (2008). Exploring the relations among the nature of the abuse, perceived parental support, and child's self-concept and trauma symptoms among sexually abused children. $J$ Child Sex Abus 17, 51-70.

Kim, J. (2008). The protective effects of religiosity on maladjustment among maltreated and nonmaltreated children. Child Abuse Negl 32, 711-20.

Walsh, K., Blaustein, M., Knight, W. G., Spinazzola, J. \& van der Kolk, B. A. (2007). Resiliency factors in the relation between childhood sexual abuse and adulthood sexual assault in college-age women. $J$ Child Sex Abus 16, 1-17.

Banyard, V. L., Williams, L. M. \& Siegel, J. A. (2002). Re-traumatization among adult women sexually abused in childhood: exploratory analyses in a prospective study. J Child Sex Abus 11, 19-48.

Traina, D. (2008). Resilience in mothers who had been victims of physical child abuse: an exploration of the mediating effects of personality characteristics, coping skills, social support, and family characteristics. Seton Hall University.

MCclure, F., Chavez, D., Agars, M., Peacock, M. \& Matosian, A. (2008). Resilience in sexually abused women: risk and protective factors. J Fam Viol $\mathbf{2 3}, 81-88$.

Haskett, M. E., Allaire, J. C., Kreig, S. \& Hart, K. C. (2008). Protective and vulnerability factors for physically abused children: effects of ethnicity and parenting context. Child Abuse Negl 32, 567-76.

Eisenberg, M. E., Ackard, D. M. \& Resnick, M. D. (2007). Protective factors and suicide risk in adolescents with a history of sexual abuse. J Pediatr 151, 482-7.

Collishaw, S., Pickles, A., Messer, J., Rutter, M., Shearer, C. \& Maughan, B. (2007). Resilience to adult psychopathology following childhood maltreatment: evidence from a community sample. Child Abuse Negl 31, 211-29. 
This is a post-peer-review, pre-copyedit version of an article published in 'Social Indicators Research'. The final authenticated version is available online at: https://doi.org/10.1007/s11205-015-0941-6. The following terms of use apply: https://www.sprin

DuMont, K. A., Widom, C. S. \& Czaja, S. J. (2007). Predictors of resilience in abused and neglected children grown-up: the role of individual and neighborhood characteristics. Child Abuse Negl 31, 255-74.

Jaffee, S. R., Caspi, A., Moffitt, T. E., Polo-Tomas, M. \& Taylor, A. (2007). Individual, family, and neighborhood factors distinguish resilient from non-resilient maltreated children: a cumulative stressors model. Child Abuse Negl 31, 231-53.

Cicchetti, D. \& Rogosch, F. A. (2007). Personality, adrenal steroid hormones, and resilience in maltreated children: a multilevel perspective. Dev Psychopathol 19, 787-809.

Liang, B., Williams, L. M. \& Siegel, J. A. (2006). Relational outcomes of childhood sexual trauma in female survivors: a longitudinal study. J Interpers Violence 21, 42-57.

Nomura, Y., Chemtob, C. M., Fifer, W. P., Newcorn, J. H. \& Brooks-Gunn, J. (2006). Additive interaction of child abuse and perinatal risk as signs of resiliency in adulthood. Ann N Y Acad Sci 1094, 330-4.

Flores, E., Cicchetti, D. \& Rogosch, F. A. (2005). Predictors of resilience in maltreated and nonmaltreated Latino children. Dev Psychol 41, 338-51.

Lyle-Lahroud, T. (2005). The influence of childhood maltreatment on adolescent adjustment: The mediating role of cognitive appraisals and coping strategies. University of Texas.

Kaufman, J., Yang, B. Z., Douglas-Palumberi, H., Houshyar, S., Lipschitz, D., Krystal, J. H. \& Gelernter, J. (2004). Social supports and serotonin transporter gene moderate depression in maltreated children. Proc Natl Acad Sci U S A 101, 17316-21.

Leifer, M., Kilbane, T. \& Kallick, S. (2004). Vulnerability or resilience to intergenerational sexual abuse: the role of maternal factors. Child Maltreat 9, 78-91.

Kim, J. \& Cicchetti, D. (2003). Social self-efficacy and behavior problems in maltreated and nonmaltreated children. J Clin Child Adolesc Psychol 32, 106-17.

Lynch, K. (2002). Children Exposed to Domestic Violence: Resiliency and the Mother-Child Relationship. University of Montana.

Bolger, K. E. \& Patterson, C. J. (2001). Pathways from child maltreatment to internalizing problems: perceptions of control as mediators and moderators. Dev Psychopathol 13, 91340 .

Morrow, J. (2001). Childhood trauma, family functioning and adult health: Protective factors as mediating variables. University of Rhode Island.

Sagy, S. \& Dotan, N. (2001). Coping resources of maltreated children in the family: a salutogenic approach. Child Abuse Negl 25, 1463-80.

Varia, R. \& Abidin, R. R. (1999). The minimizing style: perceptions of psychological abuse and quality of past and current relationships. Child Abuse Negl 23, 1041-55.

Feiring, C., Taska, L. \& Lewis, M. (1998). Social support and children's and adolescents' adaptation to sexual abuse. Journal of Interpersonal Violence 13, 240-260. 
This is a post-peer-review, pre-copyedit version of an article published in 'Social Indicators Research'. The final authenticated version is available online at: https://doi.org/10.1007/s11205-015-0941-6. The following terms of use apply: https://www.sprin

Cicchetti, D. \& Rogosch, F. A. (1997). The role of self-organization in the promotion of resilience in maltreated children. Dev Psychopathol 9, 797-815.

Lam, J. N. \& Grossman, F. K. (1997). Resiliency and adult adaptation in women with and without self-reported histories of childhood sexual abuse. J Trauma Stress 10, 175-96.

Liem, J. H., James, J. B., O'Toole, J. G. \& Boudewyn, A. C. (1997). Assessing resilience in adults with histories of childhood sexual abuse. Am J Orthopsychiatry 67, 594-606.

Toth, S. L. \& Cicchetti, D. (1996). The impact of relatedness with mother on school functioning in maltreated children. Journal of School Psychology 34, 247-266.

Moran, P. B. \& Eckenrode, J. (1992). Protective personality characteristics among adolescent victims of maltreatment. Child Abuse Negl 16, 743-54.

Scalzo, J. (1991). Beyond survival: Keys to resilience among women who experienced childhood sexual abuse. Simon Fraser University. 
This is a post-peer-review, pre-copyedit version of an article published in 'Social Indicators Research'. The final authenticated version is available online at: https://doi.org/10.1007/s11205-015-0941-6. The following terms of use apply: https://www.sprin

Table 1 A summary of the selected articles in this review

\begin{tabular}{|c|c|c|c|c|c|c|c|c|}
\hline Authors & Year & $\begin{array}{l}\text { Study } \\
\text { setting }\end{array}$ & $\begin{array}{l}\text { Sample } \\
\text { size }\end{array}$ & $\begin{array}{l}\text { Study } \\
\text { design }\end{array}$ & $\begin{array}{l}\text { Resilient or } \\
\text { protective factors }\end{array}$ & Outcome & $\begin{array}{l}\text { Type of } \\
\text { childhood } \\
\text { maltreatment }\end{array}$ & $\begin{array}{l}\text { Groups by major objectives of the } \\
\text { original studies }\end{array}$ \\
\hline \multicolumn{9}{|c|}{ Group I: Resilience associated with better life outcomes } \\
\hline Beutel et al. & 2017 & Germany & 2508 & $\begin{array}{l}\text { Cross- } \\
\text { sectional }\end{array}$ & Resilience & Distress & All & $\begin{array}{l}\mathrm{I}=\text { whether resilience associated with } \\
\text { better life outcomes }\end{array}$ \\
\hline Kim et al. & 2017 & South Korea & 169 & $\begin{array}{l}\text { Cross- } \\
\text { sectional }\end{array}$ & Resilience & $\begin{array}{l}\text { Post-traumatic stress } \\
\text { symptoms }\end{array}$ & All & $\begin{array}{l}\mathrm{I}=\text { whether resilience associated with } \\
\text { better life outcomes }\end{array}$ \\
\hline Tlapek et al. & 2017 & USA & 237 & $\begin{array}{l}\text { Cross- } \\
\text { sectional }\end{array}$ & Resilience & $\begin{array}{l}\text { Depression, PTSD, } \\
\text { substance abuse and } \\
\text { revictimization }\end{array}$ & All & $\begin{array}{l}\mathrm{I}=\text { whether resilience associated with } \\
\text { better life outcomes }\end{array}$ \\
\hline Arslan & 2016 & Turkey & 937 & $\begin{array}{l}\text { Cross- } \\
\text { sectional }\end{array}$ & Resilience & $\begin{array}{l}\text { Behaviroal and emotional } \\
\text { problems }\end{array}$ & $\begin{array}{l}\text { Psychological } \\
\text { abuse }\end{array}$ & $\begin{array}{l}\mathrm{I}=\text { whether resilience associated with } \\
\text { better life outcomes }\end{array}$ \\
\hline $\begin{array}{l}\text { Sexton } \\
\text { et al. }\end{array}$ & 2015 & USA & 214 & $\begin{array}{l}\text { Longitudinal } \\
\text { cohort }\end{array}$ & Resilience & $\begin{array}{l}\text { Posttraumatic stress, } \\
\text { depression, family } \\
\text { functioning, postpartum } \\
\text { sense of competence }\end{array}$ & All & $\begin{array}{l}\text { I=whether resilience associated with } \\
\text { better life outcomes }\end{array}$ \\
\hline $\begin{array}{l}\text { Wingo } \\
\text { et al. }\end{array}$ & 2014 & USA & 2024 & $\begin{array}{l}\text { Cross- } \\
\text { sectional }\end{array}$ & Resilience & Alcohol use, illicit drug use & All & $\begin{array}{l}\text { I=whether resilience associated with } \\
\text { better life outcomes }\end{array}$ \\
\hline $\begin{array}{l}\text { Edwards } \\
\text { et al. }\end{array}$ & 2014 & USA & 765 & $\begin{array}{l}\text { Longitudinal } \\
\text { cohort }\end{array}$ & Resilience & $\begin{array}{l}\text { Bio-psycho-social } \\
\text { functioning (psychological } \\
\text { distress, physical health } \\
\text { distress, interpersonal } \\
\text { distress) }\end{array}$ & All & $\begin{array}{l}\mathrm{I}=\text { whether resilience associated with } \\
\text { better life outcomes }\end{array}$ \\
\hline $\begin{array}{l}\text { Schulz } \\
\text { et al. }\end{array}$ & 2014 & Germany & 2046 & Cohort & Resilience & Major depressive disorder & All & $\begin{array}{l}\text { I=whether resilience associated with } \\
\text { better life outcomes }\end{array}$ \\
\hline
\end{tabular}


This is a post-peer-review, pre-copyedit version of an article published in 'Social Indicators Research'. The final authenticated version is available online at: https://doi.org/10.1007/s11205-015-0941-6. The following terms of use apply: https://www.sprin

\begin{tabular}{|c|c|c|c|c|c|c|c|c|}
\hline $\begin{array}{l}\text { Wingo } \\
\text { et al. }\end{array}$ & 2010 & USA & 792 & $\begin{array}{l}\text { Cross- } \\
\text { sectional }\end{array}$ & Resilience & Depression & All & $\begin{array}{l}\text { I=whether resilience associated with } \\
\text { better life outcomes }\end{array}$ \\
\hline $\begin{array}{l}\text { Graham- } \\
\text { Bermann }\end{array}$ & 2009 & USA & 219 & $\begin{array}{l}\text { Cross- } \\
\text { sectional }\end{array}$ & Resilience & $\begin{array}{l}\text { Social and emotional } \\
\text { adjustment }\end{array}$ & $\begin{array}{l}\text { Intimate partner } \\
\text { violence }\end{array}$ & $\begin{array}{l}\mathrm{I}=\text { whether resilience associated with } \\
\text { better life outcomes }\end{array}$ \\
\hline Kaufman & 2005 & USA & 195 & $\begin{array}{l}\text { Case- } \\
\text { control }\end{array}$ & $\begin{array}{l}\text { Multidimensional } \\
\text { resilience }\end{array}$ & Adaptive functioning & All & $\begin{array}{l}\text { I=whether resilience associated with } \\
\text { better life outcomes }\end{array}$ \\
\hline
\end{tabular}

Group II: Protective factors associated with better life outcomes

\begin{tabular}{|c|c|c|c|c|c|c|c|c|}
\hline $\begin{array}{l}\text { Baytunca } \\
\text { et al. }\end{array}$ & 2017 & Turkey & 181 & $\begin{array}{l}\text { Cross- } \\
\text { sectional }\end{array}$ & $\begin{array}{l}\text { Family integrity and } \\
\text { school attendance }\end{array}$ & $\begin{array}{l}\text { Absence of } \\
\text { psychopathology }\end{array}$ & Sexual abuse & $\begin{array}{l}\text { II=which protective factor worked } \\
\text { Ila: Mental health problems }\end{array}$ \\
\hline $\begin{array}{l}\text { Miller-Graff } \\
\text { et al. }\end{array}$ & 2017 & USA & 783 & $\begin{array}{l}\text { Cross- } \\
\text { sectional }\end{array}$ & Social support & Social competence & All & $\begin{array}{l}\text { II =which protective factor worked } \\
\text { II d: Interpersonal relationships }\end{array}$ \\
\hline Lind et al. & 2017 & USA & 1423 & $\begin{array}{l}\text { Longitudinal } \\
\text { cohort }\end{array}$ & Parental warmth & Psychiatric resilience & Sexual abuse & $\begin{array}{l}\text { II=which protective factor worked } \\
\text { Ila: Mental health problems }\end{array}$ \\
\hline $\begin{array}{l}\text { Mohr } \\
\text { \&Rosen }\end{array}$ & 2017 & USA & 501 & $\begin{array}{l}\text { Cross- } \\
\text { sectional }\end{array}$ & $\begin{array}{l}\text { Acceptance, emotional } \\
\text { support, positive } \\
\text { reframing }\end{array}$ & Posttraumatic growth & All & $\begin{array}{l}\text { II = which protective factor worked } \\
\text { II c: Adaptive functioning }\end{array}$ \\
\hline Go et al. & 2017 & Singapore & 130 & $\begin{array}{l}\text { Cross- } \\
\text { sectional }\end{array}$ & $\begin{array}{l}\text { Having } \\
\text { talents/interests, family } \\
\text { relationships, } \\
\text { educational support, } \\
\text { the role of recognition } \\
\text { and application of } \\
\text { these strengths }\end{array}$ & Conduct problems & All & $\begin{array}{l}\text { II=which protective factor worked } \\
\text { Ila: Mental health problems }\end{array}$ \\
\hline Oshri et al. & 2017 & USA & 1179 & $\begin{array}{l}\text { Longitudinal } \\
\text { cohort }\end{array}$ & Social skills & $\begin{array}{l}\text { Positive youth development } \\
\text { and resilience }\end{array}$ & All & II =which protective factor worked \\
\hline
\end{tabular}


This is a post-peer-review, pre-copyedit version of an article published in 'Social Indicators Research'. The final authenticated version is available online at: https://doi.org/10.1007/s11205-015-0941-6. The following terms of use apply: https://www.sprin

\begin{tabular}{|c|c|c|c|c|c|c|c|c|}
\hline & & & & & & & & II c: Adaptive functioning \\
\hline Shafa & 2017 & USA & 3275 & $\begin{array}{l}\text { Longitudinal } \\
\text { cohort }\end{array}$ & $\begin{array}{l}\text { Positive family } \\
\text { experience and sibling } \\
\text { relationship }\end{array}$ & $\begin{array}{l}\text { Emotional functioning and } \\
\text { problems }\end{array}$ & $\begin{array}{l}\text { Physical and } \\
\text { sexual abuse }\end{array}$ & $\begin{array}{l}\text { II=which protective factor worked } \\
\text { Ila: Mental health problems }\end{array}$ \\
\hline $\begin{array}{l}\text { Hardner } \\
\text { et al. }\end{array}$ & 2017 & USA & 260 & $\begin{array}{l}\text { Retrospecti } \\
\text { ve cohort } \\
\text { study }\end{array}$ & $\begin{array}{l}\text { Higher eduction } \\
\text { attainment }\end{array}$ & $\begin{array}{l}\text { Trauma symptoms, } \\
\text { dissociation, anxiety, } \\
\text { depression, and sleep } \\
\text { problems }\end{array}$ & Sexual abuse & $\begin{array}{l}\text { II=which protective factor worked } \\
\text { Ila: Mental health problems }\end{array}$ \\
\hline Yoon et al. & 2017 & USA & 499 & $\begin{array}{l}\text { Cross- } \\
\text { sectional }\end{array}$ & Ecological factors & Aggression & All & $\begin{array}{l}\text { II =which protective factor worked } \\
\text { II g: Aggressive behavior }\end{array}$ \\
\hline $\begin{array}{l}\text { Kaye- } \\
\text { Tzadok } \\
\text { et al. }\end{array}$ & 2017 & Israel & 184 & $\begin{array}{l}\text { Case- } \\
\text { control }\end{array}$ & $\begin{array}{l}\text { Cognitive strategies of } \\
\text { hope and self- } \\
\text { forgiveness }\end{array}$ & Resilience & Sexual abuse & $\begin{array}{l}\text { II =which protective factor worked } \\
\text { II f: life satisfaction, psychological } \\
\text { wellbeing, perceived competence, and } \\
\text { self-concept }\end{array}$ \\
\hline $\begin{array}{l}\text { Schury } \\
\text { et al. }\end{array}$ & 2017 & Germany & 240 & $\begin{array}{l}\text { Cross- } \\
\text { sectional }\end{array}$ & Social support & Postnatal distress & All & $\begin{array}{l}\text { II=which protective factor worked } \\
\text { Ila: Mental health problems }\end{array}$ \\
\hline $\begin{array}{l}\text { Daigneault } \\
\text { et al. }\end{array}$ & 2016 & USA & 246 & $\begin{array}{l}\text { Cross- } \\
\text { sectional }\end{array}$ & Mindfulness & $\begin{array}{l}\text { Post-traumatic } \\
\text { symptomatology }\end{array}$ & Sexual abuse & $\begin{array}{l}\text { Il=which protective factor worked } \\
\text { Ila: Mental health problems }\end{array}$ \\
\hline Afifi et al & 2016 & Canada & 23395 & $\begin{array}{l}\text { Cross- } \\
\text { sectional }\end{array}$ & $\begin{array}{l}\text { Individual- and } \\
\text { relationship-level } \\
\text { factors }\end{array}$ & Mental health & All & $\begin{array}{l}\text { II =which protective factor worked } \\
\text { II f: life satisfaction, psychological } \\
\text { wellbeing, perceived competence, and } \\
\text { self-concept }\end{array}$ \\
\hline Arslan & 2016 & Turkey & 937 & $\begin{array}{l}\text { Cross- } \\
\text { sectional }\end{array}$ & $\begin{array}{l}\text { Resilience and self- } \\
\text { esteem }\end{array}$ & $\begin{array}{l}\text { Emotional and behavioral } \\
\text { problems }\end{array}$ & $\begin{array}{l}\text { Psychological } \\
\text { abuse }\end{array}$ & $\begin{array}{l}\text { Il=which protective factor worked } \\
\text { Ila: Mental health problems }\end{array}$ \\
\hline
\end{tabular}


This is a post-peer-review, pre-copyedit version of an article published in 'Social Indicators Research'. The final authenticated version is available online at: https://doi.org/10.1007/s11205-015-0941-6. The following terms of use apply: https://www.sprin

\begin{tabular}{|c|c|c|c|c|c|c|c|c|}
\hline $\begin{array}{l}\text { Hillmann } \\
\text { et al. }\end{array}$ & 2016 & Germany & 89 & $\begin{array}{l}\text { Cross- } \\
\text { sectional }\end{array}$ & $\begin{array}{l}\text { Secure attachment and } \\
\text { social competence }\end{array}$ & $\begin{array}{l}\text { Absence of } \\
\text { psychopathology }\end{array}$ & All & $\begin{array}{l}\text { Il=which protective factor worked } \\
\text { Ila: Mental health problems }\end{array}$ \\
\hline Taubner & 2016 & Austria & 161 & $\begin{array}{l}\text { Cross- } \\
\text { sectional }\end{array}$ & Mentalization & Violence & All & $\begin{array}{l}\text { II =which protective factor worked } \\
\text { II e: Traumatization }\end{array}$ \\
\hline Dion et al. & 2016 & Canada & 605 & $\begin{array}{l}\text { Longitudinal } \\
\text { cohort }\end{array}$ & Support from friends & Psychological distress & All & $\begin{array}{l}\text { II=which protective factor worked } \\
\text { II a: Mental health problems }\end{array}$ \\
\hline Cleary & 2016 & USA & 117 & $\begin{array}{l}\text { Cross- } \\
\text { sectional }\end{array}$ & $\begin{array}{l}\text { Social support and } \\
\text { coping style }\end{array}$ & Positive adaption & All & $\begin{array}{l}\text { II = which protective factor worked } \\
\text { II c: Adaptive functioning }\end{array}$ \\
\hline Muzik et al. & 2012016 & USA & USA 83 & $\begin{array}{l}\text { Longitudinal } \\
\text { con8B }\end{array}$ & $\begin{array}{c}\text { Longitudinal } \\
\text { Familgosboidl support }\end{array}$ & $\begin{array}{l}\text { Farnqytisadtian depPosfipartum d } \\
\text { supponittoms symptoms }\end{array}$ & $\begin{array}{l}\text { All } \\
\text { lepressive }\end{array}$ & $\begin{array}{l}\text { Il=which protective factor worked } \\
\text { II a: Mental health problems }\end{array}$ \\
\hline Aydin et al. & 2016 & Turkey & 182 & $\begin{array}{l}\text { Cross- } \\
\text { sectional }\end{array}$ & $\begin{array}{l}\text { Perceived social } \\
\text { support }\end{array}$ & Depression and PTSD & Sexual abuse & $\begin{array}{l}\text { Il=which protective factor worked } \\
\text { Ila: Mental health problems }\end{array}$ \\
\hline $\begin{array}{l}\text { Henry } \\
\text { et al. }\end{array}$ & 2015 & USA & 485 & $\begin{array}{l}\text { Longitudinal } \\
\text { cohort }\end{array}$ & $\begin{array}{l}\text { Intimate partner } \\
\text { relationships }\end{array}$ & Depressive symptoms & All & $\begin{array}{l}\text { Il=which protective factor worked } \\
\text { II a: Mental health problems }\end{array}$ \\
\hline $\begin{array}{l}\text { Gayer- } \\
\text { Anderson } \\
\text { et al. }\end{array}$ & 2015 & UK & 468 & $\begin{array}{l}\text { Case- } \\
\text { control }\end{array}$ & Social support & Psychosis (first-episode) & $\begin{array}{l}\text { Physical and } \\
\text { sexual abuse }\end{array}$ & $\begin{array}{l}\text { Il=which protective factor worked } \\
\text { Ila: Mental health problems }\end{array}$ \\
\hline $\begin{array}{l}\text { Manning } \\
\text { et al. }\end{array}$ & 2014 & USA & 201 & $\begin{array}{l}\text { Longitudinal } \\
\text { cohort }\end{array}$ & Sensitive parenting & $\begin{array}{l}\text { Children Angry reactivity } \\
\text { and California Child Q-set }\end{array}$ & $\begin{array}{l}\text { Interparental } \\
\text { violence }\end{array}$ & $\begin{array}{l}\text { II = which protective factor worked } \\
\text { II g: Aggressive behavior }\end{array}$ \\
\hline $\begin{array}{l}\text { Maples } \\
\text { et al. }\end{array}$ & 2014 & USA & 301 & $\begin{array}{l}\text { Cross- } \\
\text { sectional }\end{array}$ & $\begin{array}{l}\text { Social and emotional } \\
\text { resources }\end{array}$ & College adjustment & All & $\begin{array}{l}\text { II =which protective factor worked } \\
\text { II b: School functioning }\end{array}$ \\
\hline
\end{tabular}


This is a post-peer-review, pre-copyedit version of an article published in 'Social Indicators Research'. The final authenticated version is available online at: https://doi.org/10.1007/s11205-015-0941-6. The following terms of use apply: https://www.sprin

\begin{tabular}{|c|c|c|c|c|c|c|c|c|}
\hline $\begin{array}{l}\text { Lowell } \\
\text { et al. }\end{array}$ & 2014 & USA & 424 & $\begin{array}{l}\text { Cross- } \\
\text { sectional }\end{array}$ & Attachment & $\begin{array}{l}\text { Emotional and behavioral } \\
\text { outcomes (internalizing and } \\
\text { externalizing problems) }\end{array}$ & All & $\begin{array}{l}\text { II =which protective factor worked } \\
\text { II a: Mental health problems }\end{array}$ \\
\hline $\begin{array}{l}\text { Sperry } \\
\text { et al. }\end{array}$ & 2013 & USA & 754 & $\begin{array}{l}\text { Longitudinal } \\
\text { cohort }\end{array}$ & Social support & Psychopathology & $\begin{array}{l}\text { Physical abuse, } \\
\text { sexual abuse, } \\
\text { neglect }\end{array}$ & $\begin{array}{l}\text { II =which protective factor worked } \\
\text { II a: Mental health problems }\end{array}$ \\
\hline $\begin{array}{l}\text { Hengartner } \\
\text { et al. }\end{array}$ & 2013 & Switzerland & 511 & $\begin{array}{l}\text { Longitudinal } \\
\text { cohort }\end{array}$ & Coping, education & Personality disorders & All & $\begin{array}{l}\text { II =which protective factor worked } \\
\text { II a: Mental health problems }\end{array}$ \\
\hline $\begin{array}{l}\text { Wahab } \\
\text { et al. }\end{array}$ & 2013 & Malaysia & 51 & $\begin{array}{l}\text { Cross- } \\
\text { sectional }\end{array}$ & Living with parents & Depression & Sexual abuse & $\begin{array}{l}\text { II =which protective factor worked } \\
\text { II a: Mental health problems }\end{array}$ \\
\hline $\begin{array}{l}\text { Wilson \& } \\
\text { Scarpa }\end{array}$ & 2013 & USA & 265 & $\begin{array}{l}\text { Cross- } \\
\text { sectional }\end{array}$ & $\begin{array}{l}\text { Perceived social } \\
\text { support }\end{array}$ & PTSD & All & $\begin{array}{l}\text { II =which protective factor worked } \\
\text { II a: Mental health problems }\end{array}$ \\
\hline $\begin{array}{l}\text { Folger \& } \\
\text { O'Dougherty }\end{array}$ & 2013 & USA & 344 & $\begin{array}{l}\text { Cross- } \\
\text { sectional }\end{array}$ & $\begin{array}{l}\text { Social support from } \\
\text { family and friends }\end{array}$ & $\begin{array}{l}\text { Depressive/ anxiety } \\
\text { symptom and anger/hostility }\end{array}$ & All & $\begin{array}{l}\text { II =which protective factor worked } \\
\text { II a: Mental health problems } \\
\text { II g: Aggressive behavior }\end{array}$ \\
\hline $\begin{array}{l}\text { Whitelock } \\
\text { et al. }\end{array}$ & 2013 & UK & 47,869 & $\begin{array}{l}\text { Cross- } \\
\text { sectional }\end{array}$ & Personality & Life satisfaction & Sexual abuse & $\begin{array}{l}\text { II =which protective factor worked } \\
\text { II f: life satisfaction, psychological } \\
\text { wellbeing, perceived competence, and } \\
\text { self-concept }\end{array}$ \\
\hline $\begin{array}{l}\text { Thornberry } \\
\text { et al. }\end{array}$ & 2013 & USA & 1000 & $\begin{array}{l}\text { Longitudinal } \\
\text { cohort }\end{array}$ & $\begin{array}{l}\text { Safe stable, nurturing } \\
\text { relationships }\end{array}$ & Maltreatment perpetration & All & $\begin{array}{l}\text { II =which protective factor worked } \\
\text { II e: traumatization }\end{array}$ \\
\hline $\begin{array}{l}\text { Kim-Spoon } \\
\text { et al. }\end{array}$ & 2012 & USA & 95 & $\begin{array}{l}\text { Longitudinal } \\
\text { cohort }\end{array}$ & $\begin{array}{l}\text { Self-regulation (Parent } \\
\text { report), positive } \\
\text { parenting }\end{array}$ & $\begin{array}{l}\text { Internalizing and } \\
\text { externalizing } \\
\text { symptomatology }\end{array}$ & Physical abuse & $\begin{array}{l}\text { II =which protective factor worked } \\
\text { II a: Mental health problems }\end{array}$ \\
\hline
\end{tabular}


This is a post-peer-review, pre-copyedit version of an article published in 'Social Indicators Research'. The final authenticated version is available online at: https://doi.org/10.1007/s11205-015-0941-6. The following terms of use apply: https://www.sprin

\begin{tabular}{|c|c|c|c|c|c|c|c|c|}
\hline $\begin{array}{l}\text { Williams \& } \\
\text { Nelson- } \\
\text { Gardell }\end{array}$ & 2012 & USA & 237 & $\begin{array}{l}\text { Cross- } \\
\text { sectional }\end{array}$ & $\begin{array}{l}\text { School engagement, } \\
\text { caregiver social } \\
\text { support, hope and } \\
\text { expectancy, caregiver } \\
\text { education, SES }\end{array}$ & Psychological symptoms & Sexual abuse & $\begin{array}{l}\text { II =which protective factor worked } \\
\text { II a: Mental health problems }\end{array}$ \\
\hline NG et al. & 2011 & UK & 160 & $\begin{array}{l}\text { Case- } \\
\text { control }\end{array}$ & $\begin{array}{l}\text { Chinese factor (filial } \\
\text { piety)-FP, Inferential } \\
\text { style }\end{array}$ & Depression & All & $\begin{array}{l}\text { II =which protective factor worked } \\
\text { II a: Mental health problems }\end{array}$ \\
\hline Elkins & 2011 & USA & 171 & $\begin{array}{l}\text { Cross- } \\
\text { sectional }\end{array}$ & $\begin{array}{l}\text { Social skills, family and } \\
\text { peer context }\end{array}$ & $\begin{array}{l}\text { Internalizing, externalizing, } \\
\text { posttraumatic stress and } \\
\text { academic achievement }\end{array}$ & Sexual abuse & $\begin{array}{l}\text { II =which protective factor worked } \\
\text { II a: Mental health problems } \\
\text { II b: School functioning }\end{array}$ \\
\hline $\begin{array}{l}\text { Coohey } \\
\text { et al. }\end{array}$ & 2011 & USA & 702 & $\begin{array}{l}\text { Longitudinal } \\
\text { cohort }\end{array}$ & Intelligence & Academic achievement & All & $\begin{array}{l}\text { II =which protective factor worked } \\
\text { II b: School functioning }\end{array}$ \\
\hline $\begin{array}{l}\text { Philippe } \\
\text { et al. }\end{array}$ & 2011 & Canada & 118 & $\begin{array}{l}\text { Cross- } \\
\text { sectional }\end{array}$ & Eco-resiliency & Psychological outcomes & All & $\begin{array}{l}\text { II =which protective factor worked } \\
\text { II a: Mental health problems }\end{array}$ \\
\hline $\begin{array}{l}\text { Kim \& } \\
\text { Cicchetti }\end{array}$ & 2010 & USA & 421 & $\begin{array}{l}\text { Case- } \\
\text { control }\end{array}$ & Emotion regulation & $\begin{array}{l}\text { Internalizing and } \\
\text { externalizing } \\
\text { symptomatology (teachers) }\end{array}$ & All & $\begin{array}{l}\text { II =which protective factor worked } \\
\text { II a: Mental health problems }\end{array}$ \\
\hline Walter et al. & 2010 & USA & 402 & $\begin{array}{l}\text { Cross- } \\
\text { sectional }\end{array}$ & $\begin{array}{l}\text { Protective self- } \\
\text { cognition }\end{array}$ & PTSD & All & $\begin{array}{l}\text { II =which protective factor worked } \\
\text { II a: Mental health problems }\end{array}$ \\
\hline $\begin{array}{l}\text { Pitzer \& } \\
\text { Fingerman }\end{array}$ & 2010 & USA & 2711 & $\begin{array}{l}\text { Cross- } \\
\text { sectional }\end{array}$ & Personal control & $\begin{array}{l}\text { Physical and psychological } \\
\text { functioning }\end{array}$ & Physical abuse & $\begin{array}{l}\text { II =which protective factor worked } \\
\text { II c: Adaptive functioning }\end{array}$ \\
\hline $\begin{array}{l}\text { Powers } \\
\text { et al. }\end{array}$ & 2009 & USA & 378 & $\begin{array}{l}\text { Cross- } \\
\text { sectional }\end{array}$ & Friendship & Depression & Sexual abuse & $\begin{array}{l}\text { II =which protective factor worked } \\
\text { II a: Mental health problems }\end{array}$ \\
\hline
\end{tabular}


This is a post-peer-review, pre-copyedit version of an article published in 'Social Indicators Research'. The final authenticated version is available online at: https://doi.org/10.1007/s11205-015-0941-6. The following terms of use apply: https://www.sprin

\begin{tabular}{|c|c|c|c|c|c|c|c|c|}
\hline $\begin{array}{l}\text { Schulz } \\
\text { et al. }\end{array}$ & 2009 & USA & 997 & $\begin{array}{l}\text { Longitudinal } \\
\text { cohort }\end{array}$ & $\begin{array}{l}\text { Social competence, } \\
\text { adaptive functioning } \\
\text { skills, and peer } \\
\text { relationships }\end{array}$ & $\begin{array}{l}\text { Internalizing and } \\
\text { externalizing } \\
\text { symptomatology, reading } \\
\text { competence }\end{array}$ & All & $\begin{array}{l}\text { II =which protective factor worked } \\
\text { II a: Mental health problems }\end{array}$ \\
\hline Bruggen & 2009 & Canada & 267 & $\begin{array}{l}\text { Cross- } \\
\text { sectional }\end{array}$ & $\begin{array}{l}\text { Mentoringship, } \\
\text { emotional support }\end{array}$ & $\begin{array}{l}\text { Psychological and physical } \\
\text { maltreatment in romantic } \\
\text { relationship }\end{array}$ & $\begin{array}{l}\text { Psychological, } \\
\text { physical, sexual } \\
\text { abuse }\end{array}$ & $\begin{array}{l}\text { II =which protective factor worked } \\
\text { II e: Traumatization }\end{array}$ \\
\hline Reyes & 2008 & USA & 61 & $\begin{array}{l}\text { Cross- } \\
\text { sectional }\end{array}$ & $\begin{array}{l}\text { Self concept, perceived } \\
\text { parental support }\end{array}$ & $\begin{array}{l}\text { Self reported levels of } \\
\text { trauma symptoms }\end{array}$ & Sexual abuse & $\begin{array}{l}\text { II =which protective factor worked } \\
\text { II a: Mental health problems }\end{array}$ \\
\hline Kim & 2008 & USA & 384 & $\begin{array}{l}\text { Case- } \\
\text { control }\end{array}$ & Role of child religiosity & $\begin{array}{l}\text { Children's internalizing and } \\
\text { externalizing behaviors }\end{array}$ & All & $\begin{array}{l}\text { II =which protective factor worked } \\
\text { II a: Mental health problems }\end{array}$ \\
\hline $\begin{array}{l}\text { Walsh } \\
\text { et al. }\end{array}$ & 2008 & USA & 73 & $\begin{array}{l}\text { Cross- } \\
\text { sectional }\end{array}$ & $\begin{array}{l}\text { Self efficacy, coping } \\
\text { styles, locus of control }\end{array}$ & Adult sexual experiences & Sexual abuse & $\begin{array}{l}\text { II =which protective factor worked } \\
\text { II e: Traumatization }\end{array}$ \\
\hline $\begin{array}{l}\text { Banyard } \\
\text { et al. }\end{array}$ & 2008 & USA & 80 & $\begin{array}{l}\text { Longitudinal } \\
\text { cohort }\end{array}$ & $\begin{array}{l}\text { Social support } \\
\text { satisfaction }\end{array}$ & Re-traumatization & Sexual abuse & $\begin{array}{l}\text { II =which protective factor worked } \\
\text { II e: Traumatization }\end{array}$ \\
\hline Traina & 2008 & USA & 80 & $\begin{array}{l}\text { Cross- } \\
\text { sectional }\end{array}$ & $\begin{array}{l}\text { Coping skills, family } \\
\text { cohesion }\end{array}$ & $\begin{array}{l}\text { Child abuse potential to their } \\
\text { kids }\end{array}$ & Physical abuse & $\begin{array}{l}\text { II =which protective factor worked } \\
\text { II e: Traumatization }\end{array}$ \\
\hline $\begin{array}{l}\text { McClure } \\
\text { et al. }\end{array}$ & 2008 & USA & 177 & $\begin{array}{l}\text { Cross- } \\
\text { sectional }\end{array}$ & Family characteristics & $\begin{array}{l}\text { Psychological wellbeing, } \\
\text { self-acceptance, positive } \\
\text { relations with others, } \\
\text { environmental mastery }\end{array}$ & Sexual abuse & $\begin{array}{l}\text { II =which protective factor worked } \\
\text { II f: life satisfaction, psychological } \\
\text { wellbeing, perceived competence, and } \\
\text { self-concept }\end{array}$ \\
\hline $\begin{array}{l}\text { Haskett } \\
\text { et al. }\end{array}$ & 2008 & USA & 153 & $\begin{array}{l}\text { Case- } \\
\text { control }\end{array}$ & $\begin{array}{l}\text { Ethnicity and features } \\
\text { of parenting context }\end{array}$ & Aggressive behavior & Physical abuse & $\begin{array}{l}\text { II =which protective factor worked } \\
\text { II g: Aggressive behavior }\end{array}$ \\
\hline
\end{tabular}


This is a post-peer-review, pre-copyedit version of an article published in 'Social Indicators Research'. The final authenticated version is available online at: https://doi.org/10.1007/s11205-015-0941-6. The following terms of use apply: https://www.sprin

\begin{tabular}{|c|c|c|c|c|c|c|c|c|}
\hline $\begin{array}{l}\text { Eisenberg } \\
\text { et al. }\end{array}$ & 2007 & USA & 83731 & $\begin{array}{l}\text { Cross- } \\
\text { sectional }\end{array}$ & $\begin{array}{l}\text { Family connectedness, } \\
\text { teacher caring, other } \\
\text { adult caring, and } \\
\text { school safety }\end{array}$ & $\begin{array}{l}\text { Suicide ideation and } \\
\text { attempts }\end{array}$ & Sexual abuse & $\begin{array}{l}\text { II =which protective factor worked } \\
\text { II a: Mental health problems }\end{array}$ \\
\hline $\begin{array}{l}\text { Collishaw } \\
\text { et al. }\end{array}$ & 2007 & UK & 364 & $\begin{array}{l}\text { Longitudinal } \\
\text { cohort }\end{array}$ & $\begin{array}{l}\text { Parental care, adult } \\
\text { personality functioning, } \\
\text { relationship history }\end{array}$ & Psychopathology & $\begin{array}{l}\text { Sexual and } \\
\text { physical abuse }\end{array}$ & $\begin{array}{l}\text { II =which protective factor worked } \\
\text { II a: Mental health problems }\end{array}$ \\
\hline $\begin{array}{l}\text { DuMont } \\
\text { et al. }\end{array}$ & 2007 & USA & 676 & $\begin{array}{l}\text { Perspective } \\
\text { cohort }\end{array}$ & $\begin{array}{l}\text { Cognitive ability, stable } \\
\text { living situation, } \\
\text { neighborhood } \\
\text { advantage, supportive } \\
\text { partner or spouse }\end{array}$ & $\begin{array}{l}\text { Multiple domains of } \\
\text { functioning (education, } \\
\text { psychiatric disorder, } \\
\text { substance abuse, official } \\
\text { reports of arrests, self- } \\
\text { reports violent behavior, } \\
\text { employment, homelessness } \\
\text { and social activity }\end{array}$ & $\begin{array}{l}\text { Physical, sexual } \\
\text { abuse, and } \\
\text { neglect }\end{array}$ & $\begin{array}{l}\text { II = which protective factor worked } \\
\text { II c: Adaptive functioning }\end{array}$ \\
\hline $\begin{array}{l}\text { Jaffee } \\
\text { et al. }\end{array}$ & 2007 & USA & $\begin{array}{l}1116 \\
\text { twin } \\
\text { pairs } \\
\text { and } \\
\text { parents }\end{array}$ & $\begin{array}{l}\text { Longitudinal } \\
\text { cohort }\end{array}$ & $\begin{array}{l}\text { Above average IQ, } \\
\text { Well-adjusted } \\
\text { temperament, maternal } \\
\text { warmth, social } \\
\text { deprivation, maternal } \\
\text { depression, parental } \\
\text { antisocial personality, } \\
\text { parental substance use } \\
\text { problems, adult } \\
\text { domestic violence, } \\
\text { sibling warmth, sibling } \\
\text { conflict, crime rate, } \\
\text { social cohesion, and } \\
\text { informal social control } \\
\text { in neighbhourhood }\end{array}$ & Adaptive functioning & Physical abuse & $\begin{array}{l}\text { II =which protective factor worked } \\
\text { II c: Adaptive functioning }\end{array}$ \\
\hline $\begin{array}{l}\text { Cicchetti \& } \\
\text { Rogosch }\end{array}$ & 2007 & USA & 677 & $\begin{array}{l}\text { Case- } \\
\text { control }\end{array}$ & Personality & Resilient functioning & All & $\begin{array}{l}\text { II =which protective factor worked } \\
\text { II c: Adaptive functioning }\end{array}$ \\
\hline Liang & 2006 & USA & 136 & $\begin{array}{l}\text { Longitudinal } \\
\text { cohort }\end{array}$ & Maternal attachment & $\begin{array}{l}\text { Marital and other relational } \\
\text { outcomes }\end{array}$ & Sexual abuse & II =which protective factor worked \\
\hline
\end{tabular}


This is a post-peer-review, pre-copyedit version of an article published in 'Social Indicators Research'. The final authenticated version is available online at: https://doi.org/10.1007/s11205-015-0941-6. The following terms of use apply: https://www.sprin

\begin{tabular}{|c|c|c|c|c|c|c|c|c|}
\hline et al. & & & & & & & & II d: Interpersonal relationships \\
\hline $\begin{array}{l}\text { Nomura } \\
\text { et al. }\end{array}$ & 2006 & USA & 1748 & $\begin{array}{l}\text { Longitudinal } \\
\text { birth cohort }\end{array}$ & $\begin{array}{l}\text { Optimal birth outcomes } \\
\text { (normal birth weight } \\
\text { and full term birth) }\end{array}$ & Psychiatric problems & All & $\begin{array}{l}\text { II =which protective factor worked } \\
\text { II a: Mental health problems }\end{array}$ \\
\hline $\begin{array}{l}\text { Flores } \\
\text { et al. }\end{array}$ & 2005 & USA & 133 & $\begin{array}{l}\text { Case- } \\
\text { control }\end{array}$ & $\begin{array}{l}\text { Ego resiliency and } \\
\text { intelligence, ego over- } \\
\text { control }\end{array}$ & Resilient functioning & All & $\begin{array}{l}\text { II =which protective factor worked } \\
\text { II c: Adaptive functioning }\end{array}$ \\
\hline $\begin{array}{l}\text { Lyle- } \\
\text { Lahroud }\end{array}$ & 2005 & USA & 157 & $\begin{array}{l}\text { Cross- } \\
\text { sectional }\end{array}$ & $\begin{array}{l}\text { Cognitive appraisals } \\
\text { and coping strategies }\end{array}$ & Adolescent adjustment & All & $\begin{array}{l}\text { II =which protective factor worked } \\
\text { II c: Adaptive functioning }\end{array}$ \\
\hline $\begin{array}{l}\text { Kaufman } \\
\text { et al. }\end{array}$ & 2004 & USA & 101 & $\begin{array}{l}\text { Case- } \\
\text { control }\end{array}$ & Social support & Depression & All & $\begin{array}{l}\text { II =which protective factor worked } \\
\text { II a: Mental health problems }\end{array}$ \\
\hline $\begin{array}{l}\text { Leifer } \\
\text { et al. }\end{array}$ & 2004 & USA & 196 & $\begin{array}{l}\text { Cross- } \\
\text { sectional }\end{array}$ & $\begin{array}{l}\text { Secure attachment, } \\
\text { years living with } \\
\text { biological mothers }\end{array}$ & $\begin{array}{l}\text { Intergenerational sexual } \\
\text { abuse }\end{array}$ & Sexual abuse & $\begin{array}{l}\text { II =which protective factor worked } \\
\text { II e: Traumatization }\end{array}$ \\
\hline $\begin{array}{l}\text { Kim \& } \\
\text { Cicchetti }\end{array}$ & 2003 & USA & 500 & $\begin{array}{l}\text { Case- } \\
\text { control }\end{array}$ & Social efficacy & $\begin{array}{l}\text { Internalizing and } \\
\text { externalizing } \\
\text { symptomatology }\end{array}$ & All & $\begin{array}{l}\text { II = which protective factor worked } \\
\text { II a: Mental health problems }\end{array}$ \\
\hline Lynch & 2002 & USA & 50 & $\begin{array}{l}\text { Cross- } \\
\text { sectional }\end{array}$ & $\begin{array}{l}\text { Mother-child } \\
\text { relationship, parenting }\end{array}$ & $\begin{array}{l}\text { Psychological functioning, } \\
\text { children's internalizing and } \\
\text { externalizing problems }\end{array}$ & $\begin{array}{l}\text { Domestic } \\
\text { violence }\end{array}$ & $\begin{array}{l}\text { II =which protective factor worked } \\
\text { II a: Mental health problems } \\
\text { II c: Adaptive functioning }\end{array}$ \\
\hline $\begin{array}{l}\text { Bolger \& } \\
\text { Patterson }\end{array}$ & 2001 & USA & 785 & $\begin{array}{l}\text { Longitudinal } \\
\text { cohort }\end{array}$ & $\begin{array}{l}\text { Perceived internal } \\
\text { control }\end{array}$ & $\begin{array}{l}\text { Internalizing problem } \\
\text { (depression, anxiety, social } \\
\text { withdrawal, and somatic } \\
\text { symptoms) }\end{array}$ & All & $\begin{array}{l}\text { II =which protective factor worked } \\
\text { II a: Mental health problems }\end{array}$ \\
\hline Marrow & 2001 & USA & 451 & $\begin{array}{l}\text { Cross- } \\
\text { sectional }\end{array}$ & $\begin{array}{l}\text { Family functioning, } \\
\text { resilience scale, }\end{array}$ & Health related problems & All & $\begin{array}{l}\text { II =which protective factor worked } \\
\text { II a: Mental health problems }\end{array}$ \\
\hline
\end{tabular}


This is a post-peer-review, pre-copyedit version of an article published in 'Social Indicators Research'. The final authenticated version is available online at: https://doi.org/10.1007/s11205-015-0941-6. The following terms of use apply: https://www.sprin

\begin{tabular}{|c|c|c|c|c|c|c|c|c|}
\hline & & & & & $\begin{array}{l}\text { community support, } \\
\text { spirituality }\end{array}$ & & & \\
\hline $\begin{array}{l}\text { Sagy \& } \\
\text { Dotan }\end{array}$ & 2001 & Israel & 226 & $\begin{array}{l}\text { Case- } \\
\text { control }\end{array}$ & $\begin{array}{l}\text { Sense of family } \\
\text { coherence, } \\
\text { psychological sense of } \\
\text { school membership, } \\
\text { social support }\end{array}$ & $\begin{array}{l}\text { Perceived competence and } \\
\text { psychological distress }\end{array}$ & All & $\begin{array}{l}\text { II =which protective factor worked } \\
\text { II a: Mental health problems } \\
\text { II f: life satisfaction, psychological } \\
\text { wellbeing, perceived competence, and } \\
\text { self-concept }\end{array}$ \\
\hline $\begin{array}{l}\text { Varia \& } \\
\text { Adidin }\end{array}$ & 1999 & USA & 90 & $\begin{array}{l}\text { Cross- } \\
\text { sectional }\end{array}$ & Maternal care & Adult relationships & $\begin{array}{l}\text { Psychological } \\
\text { abuse }\end{array}$ & $\begin{array}{l}\text { II =which protective factor worked } \\
\text { II d: Interpersonal relationships }\end{array}$ \\
\hline Feiring & 1998 & USA & 154 & $\begin{array}{l}\text { Cross- } \\
\text { sectional }\end{array}$ & Social support & Psychological distress & Sexual abuse & $\begin{array}{l}\text { II =which protective factor worked } \\
\text { II a: Mental health problems }\end{array}$ \\
\hline $\begin{array}{l}\text { Cicchetti \& } \\
\text { Rogosch }\end{array}$ & 1997 & USA & 213 & $\begin{array}{l}\text { Case- } \\
\text { control }\end{array}$ & $\begin{array}{l}\text { Positive self-esteem, } \\
\text { ego resilience, ego } \\
\text { over-control }\end{array}$ & Adaptive functioning & All & $\begin{array}{l}\text { II = which protective factor worked } \\
\text { II c: Adaptive functioning }\end{array}$ \\
\hline $\begin{array}{l}\text { Lam \& } \\
\text { Grossman }\end{array}$ & 1997 & USA & 264 & $\begin{array}{l}\text { Case- } \\
\text { control }\end{array}$ & $\begin{array}{l}16 \text { protective factors } \\
\text { (16 self-report } \\
\text { variables in individual, } \\
\text { familial, and social } \\
\text { domains) }\end{array}$ & $\begin{array}{l}\text { Adult psychological and } \\
\text { social functioning }\end{array}$ & Sexual abuse & $\begin{array}{l}\text { II = which protective factor worked } \\
\text { II c: Adaptive functioning }\end{array}$ \\
\hline Liem & 1997 & UK & 145 & $\begin{array}{l}\text { Cross- } \\
\text { sectional }\end{array}$ & $\begin{array}{l}\text { Early family } \\
\text { environment, physical } \\
\text { coercion }\end{array}$ & Depression, self-esteem & $\begin{array}{l}\text { Sexual, } \\
\text { emotional abuse }\end{array}$ & $\begin{array}{l}\text { II =which protective factor worked } \\
\text { II a: Mental health problems } \\
\text { II f: life satisfaction, psychological } \\
\text { wellbeing, perceived competence, and } \\
\text { self-concept }\end{array}$ \\
\hline $\begin{array}{l}\text { Toth \& } \\
\text { Cicchetti }\end{array}$ & 1996 & USA & 61 & $\begin{array}{l}\text { Case- } \\
\text { control }\end{array}$ & $\begin{array}{l}\text { Relatedness with } \\
\text { mother }\end{array}$ & School functioning & All & $\begin{array}{l}\text { II = which protective factor worked } \\
\text { II b: School functioning }\end{array}$ \\
\hline
\end{tabular}


This is a post-peer-review, pre-copyedit version of an article published in 'Social Indicators Research'. The final authenticated version is available online at: https://doi.org/10.1007/s11205-015-0941-6. The following terms of use apply: https://www.sprin

\begin{tabular}{|c|c|c|c|c|c|c|c|c|}
\hline $\begin{array}{l}\text { Moran \& } \\
\text { Eckenrode }\end{array}$ & 1992 & USA & 145 & $\begin{array}{l}\text { Case- } \\
\text { control }\end{array}$ & $\begin{array}{l}\text { Locus of control, self- } \\
\text { esteem }\end{array}$ & Depression & All & $\begin{array}{l}\text { II =which protective factor worked } \\
\text { II a: Mental health problems }\end{array}$ \\
\hline Scalzo & 1991 & Canada & 100 & $\begin{array}{l}\text { Cross- } \\
\text { sectional }\end{array}$ & $\begin{array}{l}\text { Ego identity, coping } \\
\text { skills }\end{array}$ & $\begin{array}{l}\text { Psychological distress and } \\
\text { self-concept }\end{array}$ & Sexual abuse & $\begin{array}{l}\text { II =which protective factor worked } \\
\text { II a: Mental health problems } \\
\text { II f: life satisfaction, psychological } \\
\text { wellbeing, perceived competence, and } \\
\text { self-concept }\end{array}$ \\
\hline
\end{tabular}

Note: Type of childhood maltreatment: all includes sexual abuse, physical abuse, psychological/ emotional abuse, neglect

Appendix 2 provides the references for above selected articles, which are listed according to the order of individual reference in the table. 


\begin{tabular}{|c|c|c|}
\hline Groups & Objective factors & Self perceived factors \\
\hline Individual factors & $\begin{array}{l}\text { Optimal birth outcomes, } \\
\text { coping, education, relationship } \\
\text { history, social economic status, } \\
\text { social skills, positive coping, } \\
\text { and adaptive functioning skills. }\end{array}$ & $\begin{array}{l}\text { Self-regulation, perceived } \\
\text { internal control, attachment, } \\
\text { locus of control, self esteem, } \\
\text { ego identify, eco-resiliency, } \\
\text { emotion regulation, adult } \\
\text { personality functioning, } \\
\text { personality, social efficacy, } \\
\text { spirituality, hope } \\
\text { expectancy, protective self- } \\
\text { cognition, and social } \\
\text { competence. }\end{array}$ \\
\hline Familial factors & $\begin{array}{l}\text { Early family environment, living } \\
\text { with parents, positive } \\
\text { parenting, parental care, family } \\
\text { functioning, family and peer } \\
\text { context, role of child religiosity, } \\
\text { friendship, intimate partner } \\
\text { relationships, sibling } \\
\text { relationships, and peer } \\
\text { relationships. }\end{array}$ & $\begin{array}{l}\text { Family connectedness, } \\
\text { family integrity }\end{array}$ \\
\hline $\begin{array}{l}\text { Community/society } \\
\text { factors }\end{array}$ & $\begin{array}{l}\text { Other adult (other than family } \\
\text { members) caring, teacher } \\
\text { caring, social support, school } \\
\text { safety, community support, } \\
\text { inferential style, educational } \\
\text { support, living in a } \\
\text { neighbourhood with few } \\
\text { problems, and social } \\
\text { engagement. }\end{array}$ & \\
\hline
\end{tabular}

Table 2 A summary of protective factors associated with adaptive functioning and resilience 
This is a post-peer-review, pre-copyedit version of an article published in 'Social Indicators Research'. The final authenticated version is available online at: https://doi.org/10.1007/s11205-015-0941-6. The following terms of use apply: https://www.sprin

Table 3 Protective factors associated with better health and well-being outcomes by type of maltreatments

\begin{tabular}{|c|c|c|c|c|c|c|c|c|}
\hline $\begin{array}{l}\text { Types of } \\
\text { maltreat } \\
\text { ment }\end{array}$ & $\begin{array}{l}\text { Groups of } \\
\text { factors }\end{array}$ & $\begin{array}{l}\text { Ila: } \\
\text { Absence of } \\
\text { psychopath } \\
\text { ology }\end{array}$ & $\begin{array}{l}\text { Ill: } \\
\text { School } \\
\text { functio } \\
\text { ning }\end{array}$ & $\begin{array}{l}\text { Ilc: } \\
\text { Adaptive } \\
\text { functioni } \\
\text { ng }\end{array}$ & $\begin{array}{l}\text { Ild: } \\
\text { Interpers } \\
\text { onal } \\
\text { relations } \\
\text { hips }\end{array}$ & $\begin{array}{l}\text { Ile: } \\
\text { Traumatiz } \\
\text { ation }\end{array}$ & $\begin{array}{l}\text { Ilf: Life } \\
\text { satisficat } \\
\text { ion, } \\
\text { psycholo } \\
\text { gical } \\
\text { well- } \\
\text { being, } \\
\text { etc. }\end{array}$ & $\begin{array}{l}\text { Ilg: } \\
\text { Aggres } \\
\text { sive } \\
\text { hevior }\end{array}$ \\
\hline \multirow[t]{3}{*}{$\begin{array}{l}\text { All, } \\
\text { inclusive }\end{array}$} & $\begin{array}{l}\text { Individual } \\
\text { factors }\end{array}$ & $\begin{array}{l}\text { Secure } \\
\text { attachment, } \\
\text { ego } \\
\text { resiliency, } \\
\text { emotional } \\
\text { regulation, } \\
\text { protective } \\
\text { self- } \\
\text { cognition, } \\
\text { importance } \\
\text { of faith, } \\
\text { perceived } \\
\text { internal } \\
\text { control, self } \\
\text { esteem, } \\
\text { locus } \\
\text { control, ego } \\
\text { identity, } \\
\text { adaptive } \\
\text { coping, fillal } \\
\text { piety, social } \\
\text { competence } \\
\text {, adaptive } \\
\text { functioning } \\
\text { skills, } \\
\text { optimal birth } \\
\text { outcomes, } \\
\text { stability }\end{array}$ & $\begin{array}{l}\text { Intellige } \\
\text { nce, } \\
\text { emotion } \\
\text { al } \\
\text { resourc } \\
\text { es }\end{array}$ & $\begin{array}{l}\text { Cognitive } \\
\text { appriasal } \\
\text { s, } \\
\text { positive } \\
\text { coping, } \\
\text { ego over- } \\
\text { control, } \\
\text { ego } \\
\text { resiliency } \\
\text {, self- } \\
\text { esteem a } \\
\text { composit } \\
\text { e score } \\
\text { of } \\
\text { individual } \\
\text {, familial, } \\
\text { and } \\
\text { societal } \\
\text { factors }\end{array}$ & $\begin{array}{l}\text { No } \\
\text { studies }\end{array}$ & $\begin{array}{l}\text { Attachmen } \\
\text { t to child }\end{array}$ & $\begin{array}{l}\text { Higer } \\
\text { education } \\
\text { and } \\
\text { income, } \\
\text { physical } \\
\text { activity, } \\
\text { good } \\
\text { coping } \\
\text { skills }\end{array}$ & $\begin{array}{l}\text { No } \\
\text { studies }\end{array}$ \\
\hline & $\begin{array}{l}\text { Family/peers } \\
\text { factors }\end{array}$ & $\begin{array}{l}\text { Relationship } \\
\text { satisfication, } \\
\text { sense of } \\
\text { family } \\
\text { coherence, } \\
\text { peer } \\
\text { relationships } \\
\text {, family } \\
\text { experience, } \\
\text { sibling } \\
\text { relationships }\end{array}$ & $\begin{array}{l}\text { Related } \\
\text { ness } \\
\text { with } \\
\text { mother }\end{array}$ & $\begin{array}{l}\text { No } \\
\text { studies }\end{array}$ & $\begin{array}{l}\text { No } \\
\text { studies }\end{array}$ & $\begin{array}{l}\text { Relationsh } \\
\text { ip } \\
\text { satisficatio } \\
n\end{array}$ & $\begin{array}{l}\text { Sense of } \\
\text { family } \\
\text { coherenc } \\
\mathrm{e}\end{array}$ & $\begin{array}{l}\text { No } \\
\text { studies }\end{array}$ \\
\hline & $\begin{array}{l}\text { Community/ } \\
\text { society } \\
\text { factors }\end{array}$ & $\begin{array}{l}\text { Social } \\
\text { support, } \\
\text { social } \\
\text { efficacy, }\end{array}$ & $\begin{array}{l}\text { Social } \\
\text { resourc } \\
\text { es }\end{array}$ & $\begin{array}{l}\text { No } \\
\text { studies }\end{array}$ & $\begin{array}{l}\text { No } \\
\text { studies }\end{array}$ & $\begin{array}{l}\text { No } \\
\text { studies }\end{array}$ & $\begin{array}{l}\text { No } \\
\text { studies }\end{array}$ & $\begin{array}{l}\text { Social } \\
\text { support }\end{array}$ \\
\hline
\end{tabular}


This is a post-peer-review, pre-copyedit version of an article published in 'Social Indicators Research'. The final authenticated version is available online at: https://doi.org/10.1007/s11205-015-0941-6. The following terms of use apply: https://www.sprin

\begin{tabular}{|c|c|c|c|c|c|c|c|c|}
\hline & & $\begin{array}{l}\text { living in a } \\
\text { neighborhoo } \\
\mathrm{d} \text { with fewer } \\
\text { problems, } \\
\text { and school } \\
\text { attendance }\end{array}$ & & & & & & \\
\hline \multirow[t]{3}{*}{$\begin{array}{l}\text { Physical } \\
\text { abuse }\end{array}$} & $\begin{array}{l}\text { Individual } \\
\text { factors }\end{array}$ & $\begin{array}{l}\text { Adult } \\
\text { personality, } \\
\text { functioning, } \\
\text { adaptive } \\
\text { self- } \\
\text { regulation, }\end{array}$ & $\begin{array}{l}\text { No } \\
\text { studies }\end{array}$ & $\begin{array}{l}\text { Personal } \\
\text { control, } \\
\text { tempera } \\
\text { ment, } \\
\text { being } \\
\text { white, } \\
\text { non- } \\
\text { Hispanic, } \\
\text { stable } \\
\text { living } \\
\text { situation, } \\
\text { stressful } \\
\text { life } \\
\text { events, } \\
\text { IQ, }\end{array}$ & $\begin{array}{l}\text { No } \\
\text { studies }\end{array}$ & $\begin{array}{l}\text { Coping } \\
\text { skills }\end{array}$ & $\begin{array}{l}\text { No } \\
\text { studies }\end{array}$ & $\begin{array}{l}\text { No } \\
\text { studies }\end{array}$ \\
\hline & $\begin{array}{l}\text { Family/peers } \\
\text { factors }\end{array}$ & $\begin{array}{l}\text { Relationship } \\
\text { history, } \\
\text { positive } \\
\text { parenting, } \\
\text { parental } \\
\text { care, } \\
\text { positive } \\
\text { family } \\
\text { experience, } \\
\text { sibling } \\
\text { relationship }\end{array}$ & $\begin{array}{l}\text { No } \\
\text { studies }\end{array}$ & $\begin{array}{l}\text { maternal } \\
\text { warmth, } \\
\text { maternal } \\
\text { depressi } \\
\text { on, } \\
\text { parental } \\
\text { antisocial } \\
\text { behavior, } \\
\text { supportiv } \\
\text { e partner }\end{array}$ & $\begin{array}{l}\text { No } \\
\text { studies }\end{array}$ & $\begin{array}{l}\text { Mentorshi } \\
\mathrm{p} \text {, } \\
\text { emotional } \\
\text { support, } \\
\text { family } \\
\text { cohesion }\end{array}$ & $\begin{array}{l}\text { No } \\
\text { studies }\end{array}$ & $\begin{array}{l}\text { Parenta } \\
\text { I } \\
\text { warmth }\end{array}$ \\
\hline & $\begin{array}{l}\text { Community/ } \\
\text { society } \\
\text { factors }\end{array}$ & $\begin{array}{l}\text { Social } \\
\text { support }\end{array}$ & $\begin{array}{l}\text { No } \\
\text { studies }\end{array}$ & $\begin{array}{l}\text { Social } \\
\text { deprivati } \\
\text { on, social } \\
\text { control }\end{array}$ & $\begin{array}{l}\text { No } \\
\text { studies }\end{array}$ & $\begin{array}{l}\text { No } \\
\text { studies }\end{array}$ & $\begin{array}{l}\text { No } \\
\text { studies }\end{array}$ & $\begin{array}{l}\text { No } \\
\text { studies }\end{array}$ \\
\hline \multirow[t]{2}{*}{$\begin{array}{l}\text { Sexual } \\
\text { abuse }\end{array}$} & $\begin{array}{l}\text { Individual } \\
\text { factors }\end{array}$ & $\begin{array}{l}\text { Social skills, } \\
\text { functioning, } \\
\text { coping } \\
\text { skills, hope } \\
\text { and } \\
\text { expectancy, } \\
\text { ego identity, } \\
\text { self concept, } \\
\text { social } \\
\text { economic } \\
\text { status }\end{array}$ & $\begin{array}{l}\text { Social } \\
\text { skills }\end{array}$ & $\begin{array}{l}\text { Being } \\
\text { white, } \\
\text { non- } \\
\text { Hispanic, } \\
\text { stable } \\
\text { living } \\
\text { situation, } \\
\text { stressful } \\
\text { life } \\
\text { events }\end{array}$ & $\begin{array}{l}\text { No } \\
\text { studies }\end{array}$ & $\begin{array}{l}\text { Secure } \\
\text { attachmen } \\
t\end{array}$ & $\begin{array}{l}\text { Physical } \\
\text { coercion, } \\
\text { adaptive } \\
\text { coping } \\
\text { skills, ego } \\
\text { identity }\end{array}$ & $\begin{array}{l}\text { No } \\
\text { studies }\end{array}$ \\
\hline & $\begin{array}{l}\text { Family/peers } \\
\text { factors }\end{array}$ & $\begin{array}{l}\text { Living with } \\
\text { parents, } \\
\text { caregiver } \\
\text { education, } \\
\text { parental } \\
\text { warmth, } \\
\text { friendship, } \\
\text { family }\end{array}$ & $\begin{array}{l}\text { Peer } \\
\text { rejection }\end{array}$ & $\begin{array}{l}\text { Supportiv } \\
\text { e partner }\end{array}$ & $\begin{array}{l}\text { Maternal } \\
\text { attachme } \\
\text { nt }\end{array}$ & $\begin{array}{l}\text { Mentorshi } \\
p \text {, } \\
\text { emotional } \\
\text { support, } \\
\text { years } \\
\text { living with }\end{array}$ & $\begin{array}{l}\text { Family } \\
\text { characteri } \\
\text { stics, } \\
\text { early } \\
\text { family } \\
\text { environm } \\
\text { ent }\end{array}$ & $\begin{array}{l}\text { No } \\
\text { studies }\end{array}$ \\
\hline
\end{tabular}


This is a post-peer-review, pre-copyedit version of an article published in 'Social Indicators Research'. The final authenticated version is available online at: https://doi.org/10.1007/s11205-015-0941-6. The following terms of use apply: https://www.sprin

\begin{tabular}{|c|c|c|c|c|c|c|c|c|}
\hline & & $\begin{array}{l}\text { connectedn } \\
\text { ess, } \\
\text { parental } \\
\text { care, } \\
\text { teacher and } \\
\text { others } \\
\text { caring, } \\
\text { relationship } \\
\text { history, early } \\
\text { family } \\
\text { environment } \\
\text {, positive } \\
\text { family } \\
\text { experience, } \\
\text { sibling } \\
\text { relationship }\end{array}$ & & & & $\begin{array}{l}\text { biological } \\
\text { mothers }\end{array}$ & & \\
\hline & $\begin{array}{l}\text { Community/ } \\
\text { society } \\
\text { factors }\end{array}$ & $\begin{array}{l}\text { Social } \\
\text { support, } \\
\text { school } \\
\text { engagement } \\
\text {, school } \\
\text { safety, }\end{array}$ & $\begin{array}{l}\text { No } \\
\text { studies }\end{array}$ & $\begin{array}{l}\text { No } \\
\text { studies }\end{array}$ & $\begin{array}{l}\text { No } \\
\text { studies }\end{array}$ & $\begin{array}{l}\begin{array}{l}\text { Self } \\
\text { efficacy, }\end{array} \\
\text { locus } \\
\text { control, } \\
\text { social } \\
\text { support }\end{array}$ & $\begin{array}{l}\text { No } \\
\text { studies }\end{array}$ & $\begin{array}{l}\text { No } \\
\text { studies }\end{array}$ \\
\hline \multirow[t]{3}{*}{$\begin{array}{l}\text { Emotion } \\
\text { al abuse }\end{array}$} & $\begin{array}{l}\text { Individual } \\
\text { factors }\end{array}$ & $\begin{array}{l}\text { Physical } \\
\text { coercion }\end{array}$ & $\begin{array}{l}\text { No } \\
\text { studies }\end{array}$ & $\begin{array}{l}\text { No } \\
\text { studies }\end{array}$ & $\begin{array}{l}\text { No } \\
\text { studies }\end{array}$ & $\begin{array}{l}\text { No } \\
\text { studies }\end{array}$ & $\begin{array}{l}\text { Physical } \\
\text { coercion }\end{array}$ & $\begin{array}{l}\text { No } \\
\text { studies }\end{array}$ \\
\hline & $\begin{array}{l}\text { Family/peers } \\
\text { factors }\end{array}$ & $\begin{array}{l}\text { Mother-child } \\
\text { relationship, } \\
\text { parenting, } \\
\text { early family } \\
\text { environment }\end{array}$ & $\begin{array}{l}\text { No } \\
\text { studies }\end{array}$ & $\begin{array}{l}\text { Parentin } \\
\mathrm{g}\end{array}$ & $\begin{array}{l}\text { Maternal } \\
\text { care }\end{array}$ & $\begin{array}{l}\text { Mentorshi } \\
\mathrm{p} \text {, } \\
\text { emotional } \\
\text { support }\end{array}$ & $\begin{array}{l}\text { early } \\
\text { family } \\
\text { environm } \\
\text { ent, }\end{array}$ & $\begin{array}{l}\text { Sensitiv } \\
\mathrm{e} \\
\text { parentin } \\
\mathrm{g}\end{array}$ \\
\hline & $\begin{array}{l}\text { Community/ } \\
\text { society } \\
\text { factors }\end{array}$ & No studies & $\begin{array}{l}\text { No } \\
\text { studies }\end{array}$ & $\begin{array}{l}\text { Mother- } \\
\text { child } \\
\text { relations } \\
\text { hip }\end{array}$ & $\begin{array}{l}\text { No } \\
\text { studies }\end{array}$ & $\begin{array}{l}\text { No } \\
\text { studies }\end{array}$ & $\begin{array}{l}\text { No } \\
\text { studies }\end{array}$ & $\begin{array}{l}\text { No } \\
\text { studies }\end{array}$ \\
\hline \multirow[t]{3}{*}{ Neglect } & $\begin{array}{l}\text { Individual } \\
\text { factors }\end{array}$ & No studies & $\begin{array}{l}\text { No } \\
\text { studies }\end{array}$ & $\begin{array}{l}\text { Being } \\
\text { white, } \\
\text { non- } \\
\text { Hispanic, } \\
\text { stressful } \\
\text { life } \\
\text { events, } \\
\text { stable } \\
\text { living } \\
\text { situation }\end{array}$ & $\begin{array}{l}\text { No } \\
\text { studies }\end{array}$ & $\begin{array}{l}\text { No } \\
\text { studies }\end{array}$ & $\begin{array}{l}\text { No } \\
\text { studies }\end{array}$ & $\begin{array}{l}\text { No } \\
\text { studies }\end{array}$ \\
\hline & $\begin{array}{l}\text { Family/peers } \\
\text { factors }\end{array}$ & No studies & $\begin{array}{l}\text { No } \\
\text { studies }\end{array}$ & $\begin{array}{l}\text { Supportiv } \\
\text { e partner }\end{array}$ & $\begin{array}{l}\text { No } \\
\text { studies }\end{array}$ & $\begin{array}{l}\text { No } \\
\text { studies }\end{array}$ & $\begin{array}{c}\text { No } \\
\text { studies }\end{array}$ & $\begin{array}{c}\text { No } \\
\text { studies }\end{array}$ \\
\hline & $\begin{array}{l}\text { Community/ } \\
\text { society } \\
\text { factors }\end{array}$ & No studies & $\begin{array}{l}\text { No } \\
\text { studies }\end{array}$ & & $\begin{array}{l}\text { No } \\
\text { studies }\end{array}$ & $\begin{array}{l}\text { No } \\
\text { studies }\end{array}$ & $\begin{array}{c}\text { No } \\
\text { studies }\end{array}$ & $\begin{array}{c}\text { No } \\
\text { studies }\end{array}$ \\
\hline
\end{tabular}


This is a post-peer-review, pre-copyedit version of an article published in 'Social Indicators Research'. The final authenticated version is available online at: https://doi.org/10.1007/s11205-015-0941-6. The following terms of use apply: https://www.sprin
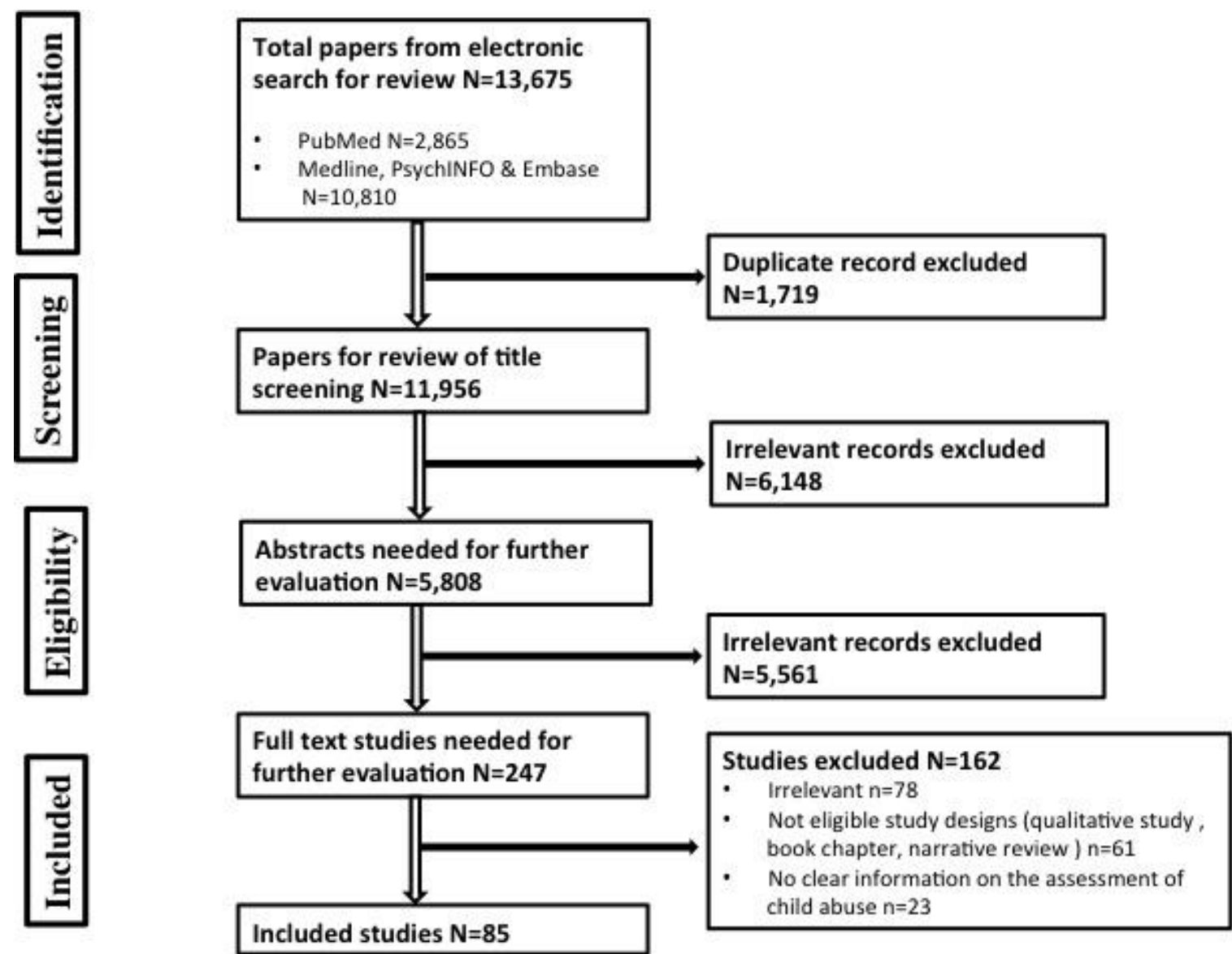

Figure 1. The process of studies selection 
This is a post-peer-review, pre-copyedit version of an article published in 'Social Indicators Research'. The final authenticated version is available online at: https://doi.org/10.1007/s11205-015-0941-6. The following terms of use apply: https://www.sprin



Figure 2. A summary of studies on protective factors associated with better health and wellbeing following the exposure of childhood maltreatment 